\title{
Biogeochemical characterization of the riverine particulate organic matter transferred to the NW Mediterranean Sea
}

\author{
M. Higueras ${ }^{1,2}$, P. Kerhervé ${ }^{1,2}$, A. Sanchez-Vidal ${ }^{3}$, A. Calafat ${ }^{3}$, W. Ludwig ${ }^{1,2}$, M. Verdoit-Jarraya ${ }^{1,2}$, S. Heussner ${ }^{1,2}$, \\ and M. Canals ${ }^{3}$ \\ ${ }^{1}$ University Perpignan Via Domitia, CEntre de Formation et de Recherche sur les Environnements Méditerranéens, \\ UMR5110, 66860, Perpignan, France \\ ${ }^{2}$ CNRS, CEntre de Formation et de Recherche sur les Environnements Méditerranéens, UMR5110, 66860, Perpignan, France \\ ${ }^{3}$ GRC Geociències Marines, Departament d'Estratigrafia, Paleontologia i Geociències Marines, Facultat de Geologia, \\ Universitat de Barcelona, 08028 Barcelona, Spain
}

Correspondence to: M. Higueras (marina.higueras@univ-perp.fr)

Received: 19 July 2013 - Published in Biogeosciences Discuss.: 8 August 2013

Revised: 29 November 2013 - Accepted: 2 December 2013 - Published: 10 January 2014

\begin{abstract}
A large amount of terrestrial organic matter is annually delivered by rivers to the continental shelf, where this material is either degraded, buried or transferred to the deep sea by hydrodynamic processes such as storms. The relative amount of terrestrial organic matter in the marine sediments is often determined by analysing the stable isotopes $\left(\delta^{13} \mathrm{C}\right.$ and $\left.\delta^{15} \mathrm{~N}\right)$ and the $\mathrm{C} / \mathrm{N}$ ratio of organic matter because the various particulate organic matter (POM) sources have distinct isotopic compositions. With the objective to refine and better interpret POM sources in the marine environment, we have characterized monthly terrestrial POM delivered by eight rivers discharging to the NW Mediterranean Sea: the Rhône, Hérault, Orb, Aude, Têt, Fluvià, Ter and Tordera rivers. These rivers were simultaneously sampled from November 2008 to December 2009 and the concentrations of total suspended matter (TSM), particulate organic carbon (POC) and nitrogen (PN), as well as their stable isotopic ratios $\left(\delta^{13} \mathrm{C}\right.$ and $\left.\delta^{15} \mathrm{~N}\right)$ were determined.

During the survey, three rainstorm events with winds coming from the E-NE and the S-SE impacted the NW Mediterranean. Depending on the direction of incoming winds, the fluvial response (amount of water discharge and TSM) was different. Rivers draining the Alps (Rhône River) and Central Massif (Hérault, Orb, and Aude rivers) were mostly impacted by rainstorms associated with winds coming from the S-SE, while rivers draining the Pyrenees (Têt, Fluvià, and Ter rivers) and the Montseny Massif (Tordera River) were impacted by rainstorms associated with winds coming from
\end{abstract}

the E-NE. In addition, the spatial evolution of water discharges shows a different hydrological regime of the Rhône River, with relatively constant and high water stages and TSM concentrations when compared to coastal rivers, characterized by long periods of low water stages. TSM concentrations are positively correlated to water discharges (high water flows resuspended riverbed sediments) but show an inverse relationship with POC and PN relative contents (mostly due to dilution and by low availability of light in river waters during flood events). TSM in most of the coastal rivers have on average 2.5-3 times higher POC and PN mean contents than the Rhône River (8.5 and $1.5 \%$, respectively, for coastal rivers compared to 3.6 and $0.5 \%$, respectively, for the Rhône River). This discrepancy may be caused by the long drought periods in small coastal Mediterranean watersheds that enhance the eutrophication in studied coastal rivers. The $\delta^{13} \mathrm{C}$ ratios of organic matter also reflect this discrepancy between high and low water stages with values ranging from -33.2 to $-24.5 \%$. The enriched ${ }^{13} \mathrm{C}$ values $(-26.3 \pm 0.4 \%$ o for the Rhône River and $-26.9 \pm 1.2 \%$ for coastal rivers), measured during high water stages, express mostly a mixture of terrestrial source (plant remains and soils) whereas depleted ${ }^{13} \mathrm{C}$ values $(\sim-30 \%$ ) associated with low water stages exhibit a source with predominant freshwater algae. The high $\delta^{15} \mathrm{~N}$ mean values ( $>8 \%$ ) found in Têt, Ter and Tordera rivers may underline the importance of denitrification processes as a consequence of the eutrophication and anthropogenic impact. 


\section{Introduction}

Approximately $87 \%$ of Earth's land surface is connected to the oceans by rivers (Ludwig and Probst, 1998), which represent the primary pathway for water and particulate matter (mostly lithogenic particles and terrestrial organic matter) to be transported to the marine environment, contributing $35000 \mathrm{~km}^{3} \mathrm{yr}^{-1}$ of freshwater (Milliman, 2001) and $18 \mathrm{GT} \mathrm{yr}^{-1}$ of suspended sediment (Milliman and Syvitski, 1992; Ludwig and Probst, 1998; Syvitski, 2003). These inputs are highly variable over time, ranging from low river discharges and low sediment inputs to the occurrence of flood events with high sediment supplies (Wheatcroft and Borgeld, 2000).

Numerous studies have documented the delivery of sediments to the oceans from large rivers such as the Amazon (e.g. Nittrouer and DeMaster, 1996), Yellow (Huanghe) (Liu et al., 2002 and Liu et al., 2004), Ganges-Brahmaputra (Goodbred and Kuehl, 2000; Kuehl et al., 1997), and Yangtze (Changjiang) (Chen et al., 2001; Liu et al., 2007). However, Milliman and Syvitski (1992) emphasized the importance of smaller rivers $\left(<5000 \mathrm{~km}^{2}\right)$ and speculated that they may account for as much as half of the present-day sediment flux to the oceans.

River inputs play a major role in the semi-enclosed Mediterranean Sea, because changes in their inputs are potential drivers for long-term changes in the marine ecosystems (Ludwig et al., 2009). Recent studies have shown that freshwater discharges by Mediterranean rivers decreased significantly by about $20 \%$ between 1960 and 2000 (Ludwig et al., 2009). This reduction is probably the result of several stress factors, including climate change and dam construction (Ludwig et al., 2003). First, the increase of temperature during the 20th century, in particular since the late 1970s (Gulf of Lion: $0.5^{\circ} \mathrm{C}$ decade $^{-1}$ for $1979-2004$, Lespinas et al., 2010), and the decrease of precipitation during certain periods of the year in the upstream watersheds may have caused a significant water discharge reduction (López-Moreno et al., 2008; Lespinas et al., 2010). Second, rivers are highly affected by artificial river damming, often related to water extractions for irrigation, which alters the natural functioning of Mediterranean rivers. The Nile is a clear example of this, with a decrease from $40-45$ to $15 \mathrm{~km}^{3}$ of freshwater discharge to the Mediterranean Sea after building the Aswan High Dam in 1964 (Schroeder et al., 2012).

At present, the Rhône River represents the major source of freshwater and terrestrial particulate matter to the Mediterranean Sea (Margat, 1992; Pettine et al, 1998; Sempéré et al., 2000). Furthermore, the Mediterranean shore is characterized by numerous coastal rivers that discharge significant amounts of water and sediment, mainly during the occurrence of short but violent flash flood events (Serrat et al., 2001; Bourrin et al., 2008). Several studies on the Rhône River have shown that the terrestrial particulate organic matter (POM) may be qualified as enough fresh, labile and mod- ern POM to drive degradation processes (Bourgeois et al., 2011; Cathalot et al., 2010) and to sustain dense macrofaunal communities in surface sediments of the prodelta (Darnaude et al., 2004; Hermand et al., 2008). Once the terrestrial POM is deposited on the prodelta, physical processes such as downwelling induced by eastern storms and dense shelf water cascading induced by cold winds are capable of transferring matter to the shelf and up to the deep sea (Palanques et al., 2006; Sanchez-Vidal et al., 2009, 2012). According to the quality of this resuspended prodelta POM, the export of terrestrial POM may sustain the biological activity up to marine sub-canyons and deep basins (Company et al., 2008; Fontanier et al;, 2008). Therefore, it is essential to accurately assess the origin and nature of the organic matter discharged by the Rhône River and also by coastal Mediterranean rivers to understand the marine carbon and nitrogen cycling on the continental margin. Riverine organic matter derives from two fundamentally different sources, which are autochthonous aquatic production and allochthonous plant detritus deposited on the ground (Finlay and Kendall, 2007). Stable isotopes offer an important tool for estimating the relative contributions of both autochthonous and allochthonous sources of terrestrial POM. Indeed, carbon and nitrogen isotopic ratios $\left(\delta^{13} \mathrm{C}\right.$ and $\left.\delta^{15} \mathrm{~N}\right)$ are widely used as natural tracers of carbon sources in riverine, estuarine and marine coastal ecosystems (Riera and Richard, 1997; Rolff and Elmgren, 2000; Darnaude et al., 2004; Wissel and Fry, 2005). In the NW Mediterranean, several studies on the Rhône River (Aucour et al., 2003; Darnaude et al., 2004; Harmelin-Vivien et al., 2010) determined the isotopic signatures of total suspended matter (TSM) within the range -27.4 to $-26.1 \%$ o for $\delta^{13} \mathrm{C}$ and 4.8 to $5.7 \%$ o for $\delta^{15} \mathrm{~N}$. Recently, the suspended matter in coastal rivers Fluvià, Ter and Tordera has been isotopically characterized by a $\delta^{13} \mathrm{C}$ mean of $28 \%$ and a $\delta^{15} \mathrm{~N}$ mean of 9.3\%o (Sanchez-Vidal et al., 2013).

To date, few coastal Mediterranean rivers have been studied and no investigations have been carried out to simultaneously trace the POM discharged by all the small and large rivers flowing into the NW Mediterranean Sea. The main objective of this current work is to accurately assess the quantity and quality of POM discharged into the NW Mediterranean Sea by the eight main rivers (from north to south: Rhône, Hérault, Orb, Aude, Têt, Fluvià, Ter and Tordera) and to investigate their role in the transport of POM according to their watersheds and anthropogenic uses, as well as the occurrence of meteorological events. This study will help us to determine the spatial and temporal variations of the riverine inputs (TSM, particulate organic carbon (POC) and nitrogen $(\mathrm{PN}))$ into the NW Mediterranean Sea and POM sources and determine their relation to water flows. 
Table 1. Main characteristics of the studied river basins ordered from north to south.

\begin{tabular}{lrrr}
\hline River & $\begin{array}{r}\text { Basin area } \\
\left(\mathrm{Km}^{2}\right)\end{array}$ & $\begin{array}{r}\text { River length } \\
(\mathrm{Km})\end{array}$ & $\begin{array}{r}\text { Annual } Q_{\text {mean }} \\
\left(\mathrm{m}^{3} \mathrm{~s}^{-1}\right)\end{array}$ \\
\hline Rhône & 97800 & 812 & 1710 \\
Hérault & 2500 & 150 & 44 \\
Orb & 1800 & 136 & 25 \\
Aude & 4840 & 224 & 49 \\
Têt & 1400 & 120 & 7.5 \\
Fluvià & 1125 & 97.2 & 9 \\
Ter & 3010 & 208 & 12 \\
Tordera & 894 & 60 & 7 \\
\hline
\end{tabular}

\section{Material and methods}

\subsection{Study area}

This study is focused on eight rivers discharging into the NW Mediterranean Sea (Fig. 1), which is characterized by warm temperatures, winter-dominated rainfall, dry summers and a profusion of microclimates due to local environmental conditions (Ludwig et al., 2003). The most important river is the Rhône River, with the largest catchment in Western Europe and the highest freshwater input into the Mediterranean Sea (Table 1). The Rhône River originates in the Alps (Switzerland) at an elevation of $2150 \mathrm{~m}$ and meets the sea at the Camargue Delta (southeastern France). In its lower course, the river receives tributaries typified by steep gradient and the predominance of a Mediterranean climate. Tributaries coming from its west bank (Central Massif) are torrential Mediterranean rivers, with low average discharges and very severe floods that occur mostly in autumn (Pont et al., 2002). Near its mouth, at $40 \mathrm{~km}$ from the sea, the river splits into two distributaries, the so-called Great Rhône and Little Rhône, carrying about 90 and $10 \%$ of the water discharge, respectively (Ibañez et al., 1997).

We also report on seven coastal Mediterranean rivers that flow into the NW Mediterranean Sea with draining catchment areas lower than $5000 \mathrm{~km}^{2}$ : the Hérault, Orb, Aude, Têt, Fluvià, Ter and Tordera rivers (Table 1). In contrast to the Rhône River, their water discharges can be torrential in character, with low water discharges during long periods except in times of heavy rainfall that cause flash floods (Paloc, 1967). Moreover, these rivers are also characterized by flowing through high percentage vegetated land and therefore can be highly affected by anthropogenic activities in their downstream parts (Lespinas et al., 2010).

These studied coastal rivers originate in Massif Central (Hérault and Orb rivers), the Pyrenees (Aude, Têt, Fluvià and Ter rivers) and Montseny Massif (Tordera River). The Hérault basin comprises very few industries and is predominantly dedicated to agriculture. It can be considered as a relatively rural watershed. The Orb watershed is character-

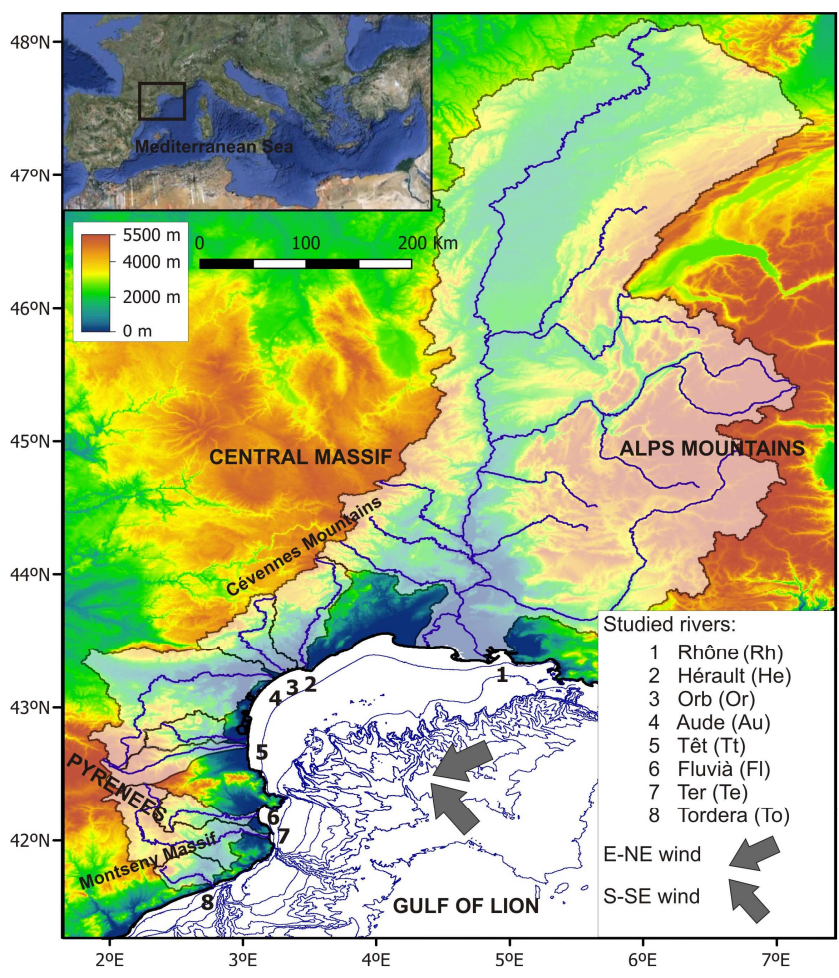

Fig. 1. Location of the study area with the eight studied rivers and their watersheds, the orography and the main wind directions.

ized by agricultural activities from the middle part to the alluvial plain. The Aude River is the longest of the investigated coastal rivers. Although originating in the Pyrenees, it follows a south-north course to Carcassonne before turning abruptly east and entering into the Mediterranean Sea. During its course, this river is also influenced by tributaries coming from the Central Massif. The Aude River plain, the tributary valleys and the moderate slopes are mainly covered by vineyards (Gaume et al., 2004). The Têt watershed is characterized by agricultural activities on the plain, as well as by the large urban waste-water treatment plant from the Perpignan district (about 150000 inhabitants) that may have an influence on the chemistry of the Têt River (GarciaEsteves et al., 2007). The Fluvià River is the only one of all the studied rivers that remains undammed along its entire course. The Fluvià watershed, as well as the watersheds of Ter and Tordera rivers are quite densely vegetated, mostly by Gramineae with woody elements and by coniferous forests, which cover around $50 \%$ of the Fluvià, Ter and Tordera watersheds (Liquete et al., 2009). It is important to note that the Ter watershed is regulated by dams $(97 \%$ of the watershed area) (Liquete et al., 2009). The Sau, Susqueda and Pasteral reservoirs are located in its middle course. The damming impact on the physical-chemical and biological characteristics of the lower stretch of the river is notable (Sabater and $\mathrm{Ar}$ mengol, 1986). 


\subsection{Sampling strategy}

The Rhône, Hérault, Orb, Aude, Têt, Fluvià, Ter and Tordera rivers were monthly and simultaneously sampled from November 2008 to December 2009. Sampling stations were located on the lower most course of each river in order to collect the particulate material that would be discharged into the sea. As the Mediterranean Sea is a microtidal sea, the marine influence is limited to the last few kilometres of all the small Mediterranean coastal rivers (Pauc, 2005). Our sampling stations were located only a few kilometres $(<4 \mathrm{~km})$ upstream of the mouths, which was far enough to guaranty the collection of freshwaters after checking its conductivity. The exception was the Rhône Observatory Station at Arles (SORA) located $45 \mathrm{~km}$ upstream from its mouth. The Rhône River receives all its tributaries at this SORA station. Furthermore, the station was designed to monitor river inputs into the Mediterranean via the Mediterranean Sea Ocean Observing System on Environment (MOOSE). Water samples of the Rhône and Têt rivers were collected from two automatic sampling stations (Arles and Villelongue-de-la-Salanque, respectively), whereas Hérault, Orb and Aude rivers were sampled from bridges at the middle of the river channels. Fluvià, Ter and Tordera rivers were sampled from the shore near the last gauging station of the Agència Catalana de L'Aigua. Twenty litres of water were collected from each river and stored one or two nights in polyethylene bottles in a refrigerated room $\left(5^{\circ} \mathrm{C}\right)$ and in darkness.

\subsection{Analytical methods}

The collected water was filtered onto four precombusted (at $450^{\circ} \mathrm{C}$ for $12 \mathrm{~h}$ ) glass fiber filters (GF/F, $47 \mathrm{~mm}$ diameter) to determine POC, PN, ${ }^{13} \mathrm{C}$ and ${ }^{15} \mathrm{~N}$. Then, filters were freezedried, weighted for determining the concentration of TSM on each filter and stored in desiccators before analysis.

Prior to the POC and ${ }^{13} \mathrm{C}$ analyses, the inorganic carbon (mainly in the form of calcium carbonate) was removed by repeated additions of $100 \mu \mathrm{L}$ of $\mathrm{HCl} 25 \%$, separated by $60^{\circ} \mathrm{C}$ drying steps until no effervescence was observed (Fabrés et al., 2002). No treatments were performed on both PN and ${ }^{15} \mathrm{~N}$ filters. Then, POC and PN contents from the Rhône, Hérault, Orb, Aude and Têt rivers were measured on a Leco CN 2000 elemental analyser (EA). Stable isotopic ratios $\left({ }^{13} \mathrm{C}\right.$ and ${ }^{15} \mathrm{~N}$ ) were separately performed on two distinct filters with an isotope ratio mass spectrometer (IR/MS, EA Eurovector3000 interfaced with a GVI Isoprime) at the CEFREM laboratory in France. Only two filters $\left(\mathrm{POC}+{ }^{13} \mathrm{C}\right.$ and $\mathrm{PN}+{ }^{15} \mathrm{~N}$ ) from the Fluvià, Ter and Tordera rivers were analysed on an elemental analyser interfaced to an IR/MS (Delta Plus Finnigan MAT, and interface GC Combustion III Finnigan MAT) at the Scientific-Technical Services of the University of Barcelona. As no $\mathrm{C}$ and $\mathrm{N}$ peaks were detected on precombusted "blank" GF/F filters, no "blank" corrections were done for POC and PN contents as well as for $\delta^{13} \mathrm{C}$ and $\delta^{15} \mathrm{~N}$ ratios. POC and PN are expressed in $\%$ of the sample dry weight, and isotopic ratios are given in the conventional $\delta$ notation:

$\delta^{13} \mathrm{Cor} \delta^{15} \mathrm{~N}=\left[\frac{R_{\text {sample }}}{R_{\text {standard }}}-1\right] \cdot 1000$

where $R$ corresponds to ${ }^{13} \mathrm{C} /{ }^{12} \mathrm{C}$ or ${ }^{15} \mathrm{~N} /{ }^{14} \mathrm{~N}$ and the reference materials are the international standards Pee Dee Belemnite (PDB) and atmospheric $\mathrm{N}_{2}$ for $\mathrm{C}$ and $\mathrm{N}$, respectively. The working standard used at the CEFREM laboratory was crushed and homogenized Rhône sediments calibrated against IAEA-CH-3 (cellulose) and IAEA-CH-7 (polyethylene) for $\delta^{13} \mathrm{C}$ analyses and IAEA-N-1 and IAEA-N-2 (ammonium sulfate) for $\delta^{15} \mathrm{~N}$ analyses. At the Barcelona laboratory, calibrations were made straight with the same IAEA reference materials completed by USGS40 (L-glutamic acid) for both $\delta^{13} \mathrm{C}$ and $\delta^{15} \mathrm{~N}$ analyses. The standard deviations from ${ }^{13} \mathrm{C}$ and ${ }^{15} \mathrm{~N}$ replicates of internal standards were lower than $0.2 \%$ at the CEFREM laboratory and 0.2 and $0.3 \%$, respectively, at the Scientific-Technical Services of the University of Barcelona.

\section{Results}

The mean water discharge $(Q)$ during the survey at the Rhône River was of $1386 \mathrm{~m}^{3} \mathrm{~s}^{-1}$, which was much larger than those recorded in the coastal rivers $\left(3-38 \mathrm{~m}^{3} \mathrm{~s}^{-1}\right)$ (Table 2). All mean water flows calculated during the survey period were lower than long-term $(40 \mathrm{yr})$ averaged values (see Table 1$)$ so the studied period can be considered as drier than usual. Time series of water discharge of the Rhône River was higher and less variable than most coastal rivers (Fig. 2). During the survey, high and punctual (a few days long) water flows were recorded in November 2008, December 2008 and February 2009, whereas a wider (a few weeks long) high water stage occurred in April-May 2009. In early November 2008, the Rhône, Hérault, Orb, and Aude rivers recorded an increase of their water flows. The highest $Q$ values were recorded in the Rhône River (up to $4806 \mathrm{~m}^{3} \mathrm{~s}^{-1}$ ) with a calculated return period of 2 years, followed by the Hérault River $\left(455 \mathrm{~m}^{3} \mathrm{~s}^{-1}\right.$, return period of $\left.1 \mathrm{yr}\right)$. Lower values were recorded in Têt, Fluvià, Ter and Tordera rivers, with $Q$ values around $20 \mathrm{~m}^{3} \mathrm{~s}^{-1}$. In late December 2008, the Têt, Fluvià, Ter and Tordera rivers reached their highest $Q$ of the studied period (up to $155.9 \mathrm{~m}^{3} \mathrm{~s}^{-1}$ ), with return periods of 1 to 3 years (Fig. 2). In early February 2009, an increase of $Q$ values up to $4848 \mathrm{~m}^{3} \mathrm{~s}^{-1}$ in the Rhône and up to 687 and $280 \mathrm{~m}^{3} \mathrm{~s}^{-1}$ in Hérault and Orb rivers, respectively (Fig. 2), were recorded. This corresponded to a return period of 1.52 yr. In addition, the Hérault, Orb, Aude, Têt and Ter rivers simultaneously recorded a significant increase of water discharges in April-May 2009 (404, 128, 178, 37, $46 \mathrm{~m}^{3} \mathrm{~s}^{-1}$, respectively). In contrast, extremely low water flows were 

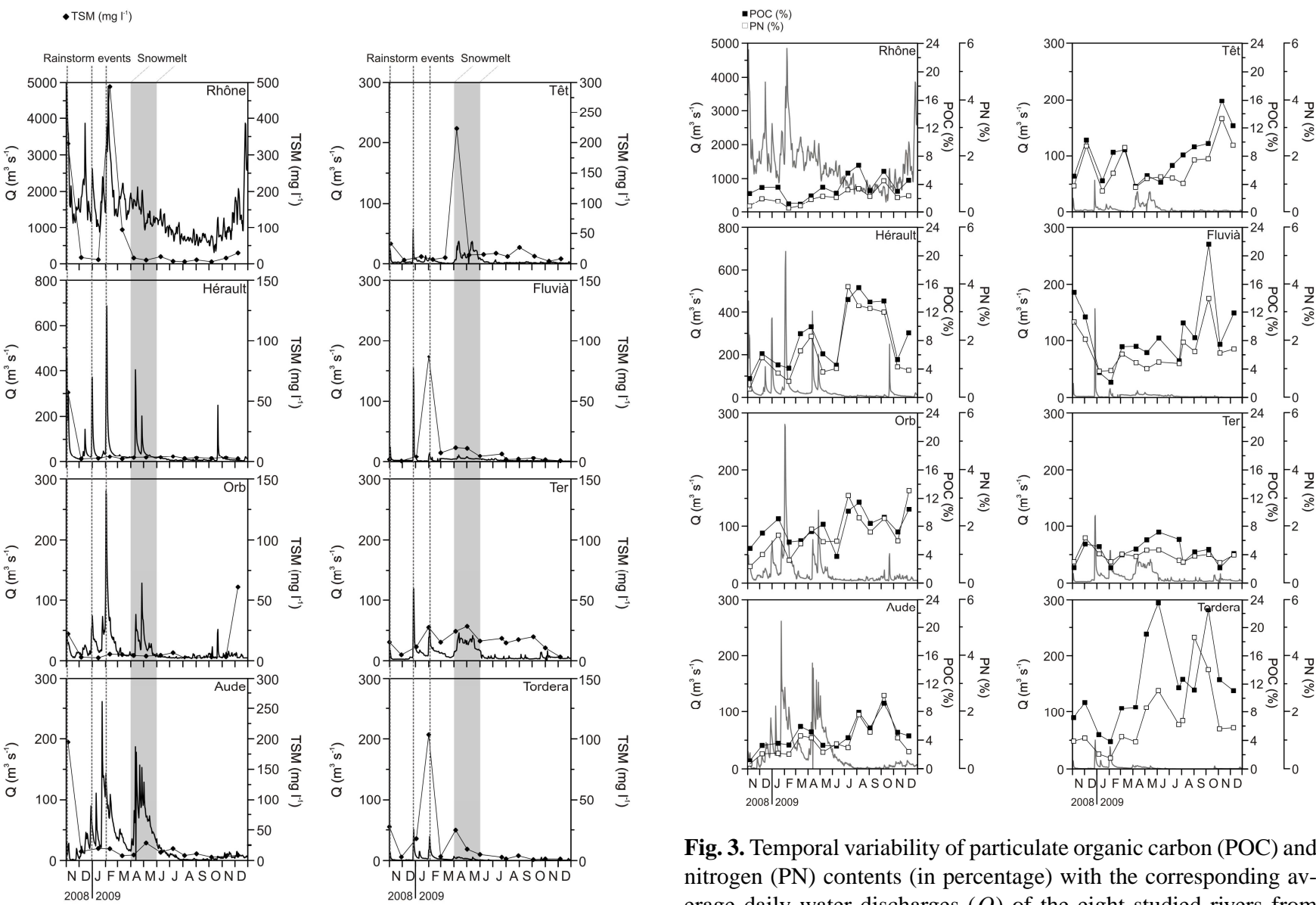

Fig. 3. Temporal variability of particulate organic carbon (POC) and nitrogen $(\mathrm{PN})$ contents (in percentage) with the corresponding average daily water discharges $(Q)$ of the eight studied rivers from November 2008 to December 2009.

Fig. 2. Average daily water discharge $(Q)$ measured at the gauging station of each studied river from November 2008 to December 2009 by Compagnie Nationale du Rhône (Rhône River), Banque Hydro France (Hérault, Orb, Aude and Têt rivers) and Agència Catalana de L'Aigua (Fluvià, Ter and Tordera rivers). The three storm events (November 2008, December 2008 and February 2009) that impacted the study area are shown as a dotted line and the snowmelt event is shown as a grey band. Plots show the temporal variability of total suspended matter (TSM) concentrations with corresponding average daily water discharge.

recorded during long periods (from July to October 2009) in coastal rivers.

TSM concentrations in the Rhône River ranged from 5.5 (to $488.7 \mathrm{mg} \mathrm{L}^{-1}$, with a mean of $71.9 \mathrm{mg} \mathrm{L}^{-1}$, whereas in the coastal rivers TSM ranged from 0.5 to $223.1 \mathrm{mg} \mathrm{L}^{-1}$ with a mean of $15.9 \mathrm{mg} \mathrm{L}^{-1}$ (Table 2). Indeed, high TSM concentration was measured in the studied rivers during the high water flows recorded in November 2008 (330.6, 57.1, 22.2 and $194.7 \mathrm{mg} \mathrm{L}^{-1}$ in the Rhône, Hérault, Orb and Aude rivers, respectively), February 2009 (488.7, 86.5, 27.5 and $103.4 \mathrm{mg} \mathrm{L}^{-1}$ in the Rhône, Fluvià, Ter and Tordera, respectively) and April-May 2009 (223.1 and $28.4 \mathrm{mg} \mathrm{L}^{-1}$ in the Têt and Ter rivers) (Fig. 2). Unfortunately, TSM were not sampled over the highest $Q$ recorded in December 2008 in 
Table 2. Water discharge $(Q)$, total suspended matter (TSM), suspended POC and PN contents, their stable isotopes $\left(\delta^{13} \mathrm{C}\right.$ and $\left.\delta^{15} \mathrm{~N}\right)$ and atomic $\mathrm{C} / \mathrm{N}$ ratios are the biogeochemical parameters measured in all studied rivers from November 2008 to December 2009 . The $Q$ data are extracted from different data bases: Compagnie Nationale du Rhône (Rhône), Banque Hydro France (Hérault, Orb, Aude and Têt) and Agència Catalana de L'Aigua (Fluvià, Ter and Tordera).

\begin{tabular}{|c|c|c|c|c|c|c|c|c|}
\hline & Rhône & Hérault & Orb & Aude & Têt & Fluvià & Ter & Tordera \\
\hline \multicolumn{9}{|l|}{$Q\left(\mathrm{~m}^{3} \mathrm{~s}^{-1}\right)$} \\
\hline Mean & 1386.3 & 34.1 & 18.3 & 28.2 & 5.0 & 3.5 & 10.8 & 3.0 \\
\hline Standard deviation & 740.7 & 71.2 & 27.4 & 37.0 & 7.2 & 9.8 & 12.5 & 5.3 \\
\hline Maximum & 4847.7 & 687.0 & 280.0 & 261.0 & 56.9 & 155.9 & 118.7 & 50.3 \\
\hline Minimum & 308.5 & 1.4 & 3.9 & 0.0 & 0.0 & 0.2 & 2.3 & 0.0 \\
\hline \multicolumn{9}{|l|}{ TSM conc. $\left(\mathrm{mg} \mathrm{L}^{-1}\right)$} \\
\hline Mean & 71.9 & 6.1 & 9.2 & 26.1 & 28.7 & 10.3 & 16.1 & 14.6 \\
\hline$Q$ weighted mean & 153.4 & 32.8 & 7.9 & 25.8 & 86.4 & 22.9 & 20.9 & 54.8 \\
\hline Standard deviation & 146.5 & 14.4 & 15.7 & 49.0 & 56.5 & 22.2 & 7.7 & 27.1 \\
\hline Maximum & 488.7 & 57.1 & 60.8 & 194.5 & 223.1 & 86.5 & 28.4 & 103.4 \\
\hline Minimum & 5.5 & 2.2 & 2.4 & 5.4 & 4.2 & 0.5 & 3.1 & 0.8 \\
\hline \multicolumn{9}{|l|}{ POC contents ( $\%$ ) } \\
\hline Mean & 3.6 & 8.4 & 7.8 & 4.7 & 8.0 & 11.4 & 7.7 & 11.9 \\
\hline$Q$ weighted mean & 3.1 & 4.6 & 6.9 & 3.9 & 5.8 & 7.0 & 7.7 & 7.1 \\
\hline Standard deviation & 1.6 & 4.3 & 2.2 & 2.1 & 3.4 & 4.1 & 1.3 & 6.0 \\
\hline Maximum & 6.7 & 15.5 & 11.5 & 9.3 & 15.8 & 22.0 & 10.0 & 23.5 \\
\hline Minimum & 1.2 & 2.7 & 3.8 & 1.1 & 3.7 & 5.7 & 5.8 & 3.8 \\
\hline \multicolumn{9}{|l|}{ PN contents $(\%)$} \\
\hline Mean & 0.5 & 1.7 & 1.8 & 1.0 & 1.6 & 1.6 & 1.0 & 1.7 \\
\hline$Q$ weighted mean & 0.4 & 0.7 & 1.3 & 0.7 & 1.2 & 1.3 & 1.0 & 0.8 \\
\hline Standard deviation & 0.3 & 1.2 & 0.8 & 0.6 & 0.7 & 0.7 & 0.2 & 1.2 \\
\hline Maximum & 1.1 & 3.9 & 3.3 & 2.6 & 3.3 & 3.5 & 1.6 & 4.6 \\
\hline Minimum & 0.1 & 0.3 & 0.6 & 0.2 & 0.8 & 0.9 & 0.7 & 0.4 \\
\hline \multicolumn{9}{|l|}{$\delta^{13} \mathrm{C}(\% \circ)$} \\
\hline Mean & -27.1 & -28.6 & -27.0 & -28.4 & -26.2 & -28.7 & -27.4 & -28.6 \\
\hline Standard deviation & 0.6 & 1.5 & 0.3 & 1.8 & 0.8 & 1.4 & 0.6 & 1.6 \\
\hline Maximum & -26.1 & -26.9 & -26.5 & -26.3 & -24.5 & -26.4 & -26.2 & -26.4 \\
\hline Minimum & -27.9 & -31.6 & -27.6 & -33.2 & -27.3 & -31.0 & -28.4 & -33.0 \\
\hline \multicolumn{9}{|l|}{$\delta^{15} \mathrm{~N}(\% \circ)$} \\
\hline Mean & 5.0 & 5.8 & 4.6 & 6.2 & 7.6 & 8.1 & 10.2 & 9.7 \\
\hline Standard deviation & 1.0 & 1.4 & 1.1 & 2.2 & 2.0 & 1.0 & 2.9 & 2.9 \\
\hline Maximum & 6.4 & 8.9 & 6.3 & 11.9 & 10.9 & 9.8 & 16.8 & 14.4 \\
\hline Minimum & 3.1 & 4.6 & 1.9 & 4.3 & 4.8 & 6.1 & 6.5 & 4.8 \\
\hline \multicolumn{9}{|l|}{$\mathrm{C} / \mathrm{N}$ ratio } \\
\hline Mean & 8.2 & 6.6 & 5.8 & 6.3 & 5.9 & 7.7 & 9.4 & 9.2 \\
\hline Standard deviation & 2.5 & 2.1 & 1.9 & 1.4 & 1.3 & 1.2 & 1.5 & 2.2 \\
\hline Maximum & 14.7 & 11.1 & 9.8 & 8.9 & 9.3 & 10.4 & 13.3 & 12.0 \\
\hline Minimum & 10.5 & 4.1 & 3.0 & 4.2 & 4.0 & 5.6 & 6.3 & 2.8 \\
\hline
\end{tabular}

and low POC and PN contents, $Q$ weighted TSM, POC and $\mathrm{PN}$ means often differ from arithmetic means for our rivers.

Stable isotopic ratios of suspended organic matter from rivers varied from $-33.2 \%$ to $-24.5 \%$ for $\delta^{13} \mathrm{C}$ and from $1.93 \%$ o to $16.8 \%$ o for $\delta^{15} \mathrm{~N}$ (Table 2). The $\delta^{13} \mathrm{C}$ values were high $(>-27 \%$ ) and relatively constant (standard deviation $< \pm 1 \%$ ) in the Rhône, Orb, Têt and Ter rivers. In contrast, values were lower $(<-28 \%$ ) and more variable (stan- dard deviation $>-1.5 \%$ ) in the Hérault, Aude, Fluvià and Tordera rivers (Fig. 4). The $\delta^{15} \mathrm{~N}$ values were low $(<6 \%$ ) and relatively constant (standard deviation around $\pm 1 \%$ ) during the survey in the Rhône, Orb and Hérault rivers. The Aude River also showed relatively low but more variable values. In contrast, high $(>7 \%$ ) and dispersed values (standard deviation $> \pm 2 \%$ ) were recorded in the Têt, Ter and Tordera 


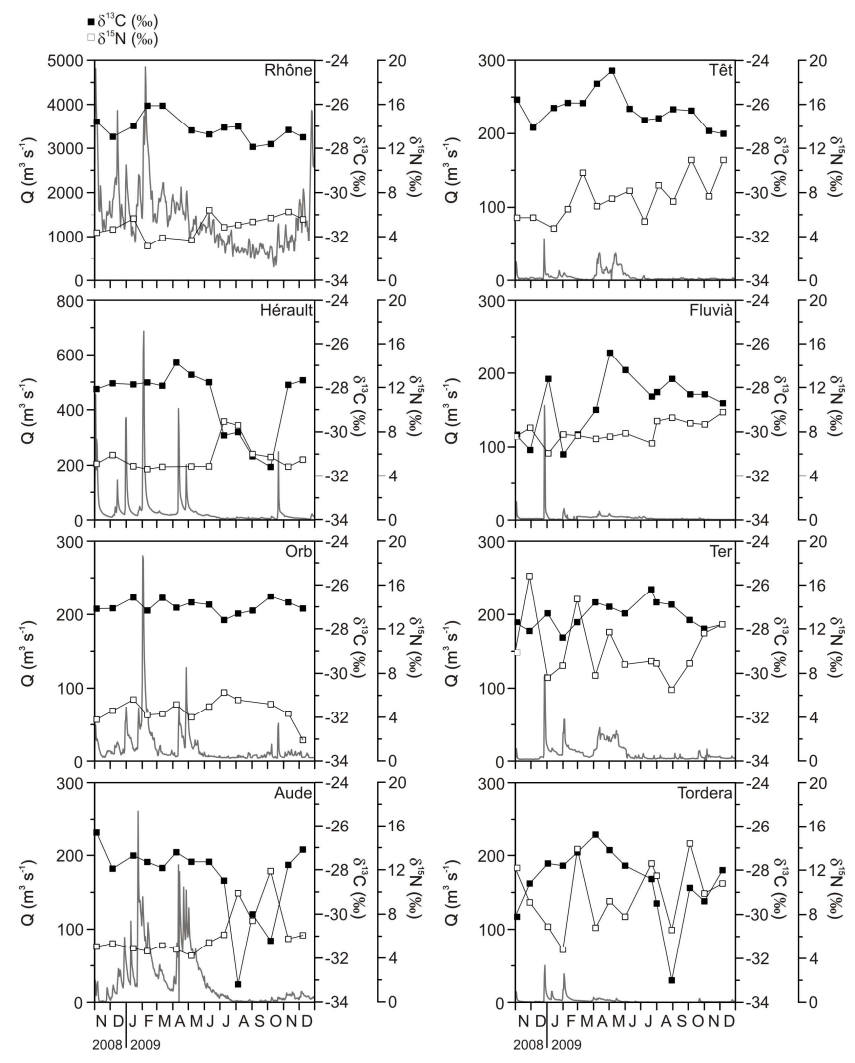

Fig. 4. Temporal variability of the stable isotopes $\left(\delta^{13} \mathrm{C}\right.$ and $\left.\delta^{15} \mathrm{~N}\right)$ with the corresponding average daily water discharges $(Q)$ of the eight studied rivers from November 2008 to December 2009.

rivers. The Fluvià River also exhibited high but almost constant $\delta^{15} \mathrm{~N}$ values (standard deviation around $\pm 1 \%$ ) (Fig. 4).

The atomic $\mathrm{C} / \mathrm{N}$ ratios of particulate organic matter varied over a large range from 2.8 to 14.7 (Table 2). The lowest values $(<3)$ were obtained in the Orb and Tordera rivers in June and September 2009. On the other hand, the Rhône, Ter and Tordera rivers recorded the highest values $(>12)$ in November 2008, February and July 2009.

\section{Discussion}

\subsection{Meteorological and hydrological drivers of continental organic matter input into the NW Mediterranean}

From a meteorological point of view, the NW Mediterranean Sea is mainly affected by N-NW, E-NE and S-SE winds. The cold, dry and persistent N-NW winds (Tramontane and Mistral) are responsible in winter for the strong cooling and homogenization of the shelf water column, which may promote dense shelf water formation over the Gulf of Lion. In contrast, heavy winds coming from E-NE $\left(90\right.$ to $\left.45^{\circ}\right)$ and S-SE $\left(180\right.$ to $\left.135^{\circ}\right)$ are warm and loaded with moisture, and when they meet the cold air aloft the Massif Central relief and the Pyrenees mountains the atmosphere becomes unstable and rain falls over these mountains. These types of rainstorms are named Cévenol when caused by S-SE winds (more frequent in the northern Gulf of Lions due to the orientation of the coast; see Fig. 1) and Llevantada when caused by E-NE winds (more frequent in the Catalan Coast). This causes sudden and elevated river discharges that can last for a few hours to days, the so-called flash flood events.

During the studied period (from November 2008 to December 2009), three rainstorm events with E-NE and S-SE wind directions impacted the study area and affected differently rivers discharging to the NW Mediterranean Sea (Fig. 2).

The first event was recorded on the 3 November 2008 following a two-month dry period. This rainstorm was associated with a mean wind direction from $170^{\circ}$ (recorded at the meteorological station of Cap Béar) and caused an increase of water flows in rivers from the Alps (Rhône River) and Central Massif (Hérault, Orb, and Aude rivers). Indeed, the Aude River, although originating in the Pyrenees, is influenced by tributaries coming from the Central Massif. On the 26 December 2008 a severe rainstorm impacted the Catalan coast (Sanchez-Vidal et al., 2012). Heavy winds blowing from $\mathrm{E}-\mathrm{NE}$ (the mean wind direction recorded at the meteorological station of Cap Béar was of $90^{\circ}$ ) triggered rainfalls associated with an increase of water flows, especially in the Pyrenees (Têt, Fluvià and Ter rivers) and the Montseny Massif (Tordera River). The third rainstorm event occurred in early February 2009. Heavy S-SE winds (the mean wind direction recorded at the meteorological station of Cap Béar was of $170^{\circ}$ ) triggered intense rainfall in the Central Massif and, thus, increased water flows in the Rhône and in the northern most coastal rivers (Hérault and Orb rivers, respectively) (Fig. 2).

The direction of the incoming wind produced different hydrological responses of the investigated rivers. Windstorms from the E-NE caused increased water discharge in rivers from the Pyrenees (Têt, Fluvià, and Ter rivers) and Montseny Massif (Tordera River) whereas windstorms from the S-SE caused increased flows of rivers from the Alps (Rhône River) and Central Massif (Hérault, Orb, and Aude rivers). In addition, some of the coastal rivers (Hérault, Orb, Aude, Têt and Ter) simultaneously recorded a significant increase of water discharges in April-May 2009. Increased insolation in spring caused snowmelt that impacted the rivers flowing from the mountains that had accumulate large amounts of snow during the winter season (mostly the Massif Central and the Pyrenees).

Therefore, rainstorms and snowmelt were the major mechanisms triggering increased water flows that can increase sediment inputs to nearshore waters of the NW Mediterranean Sea. It is well known that rapid increases of $Q$ associated with heavy rainstorms cause erosion of riverbanks and the resuspension of riverbed sediments, removing 
Table 3. TSM and POC annual estimated fluxes (2008-2009) of each studied river calculated from 14 samples using power equations: $\mathrm{TSM}=a \times Q^{b}, \mathrm{POC} \%=a \times \mathrm{TSM}^{b}$ and $\mathrm{PN} \%=a \times \mathrm{TSM}^{b}$, where $a$ and $b$ are regression coefficients. Fluxes are only calculated in rivers with a statistically significant $p$ value $(p<0.05)$.

\begin{tabular}{|c|c|c|c|c|c|}
\hline River & Equation & $n$ & $R^{2}$ & $p$ value & $\left(10^{6} \mathrm{~T} \mathrm{yr}^{-1}\right)$ \\
\hline TSM vs. $Q$ & & & & & TSM Flux \\
\hline Rhône & $\mathrm{TSM}=7.910^{-7} Q^{2.4}$ & 14 & 0.8 & $710^{-6}$ & 2.8 \\
\hline Hérault & $\mathrm{TSM}=0.8 Q^{0.5}$ & 14 & 0.6 & 0.0010 & 0.012 \\
\hline Orb & $\mathrm{TSM}=5.0 Q^{-0.1}$ & 14 & - & - & - \\
\hline Aude & $\mathrm{TSM}=7.1 Q^{0.2}$ & 14 & 0.1 & 0.3 & - \\
\hline Têt & $\mathrm{TSM}=6.1 Q^{0.8}$ & 14 & 0.5 & 0.0040 & 0.008 \\
\hline Fluvià & $\mathrm{TSM}=0.5 Q^{1.8}$ & 14 & 0.7 & 0.0001 & 0.090 \\
\hline Ter & $\mathrm{TSM}=3.1 Q^{0.6}$ & 14 & 0.3 & 0.04 & 0.008 \\
\hline Tordera & $\mathrm{TSM}=5.4 Q^{0.5}$ & 14 & 0.5 & 0.0040 & 0.001 \\
\hline POC vs. TSM & & & & & POC Flux \\
\hline Rhône & $\% \mathrm{POC}=7.6 \mathrm{TSM}^{-0.3}$ & 14 & 0.6 & 0.001 & 5.8 \\
\hline Hérault & $\% \mathrm{POC}=12.2 \mathrm{TSM}^{-0.4}$ & 14 & 0.3 & 0.04 & 0.06 \\
\hline Orb & $\% \mathrm{POC}=7.8 \mathrm{TSM}^{-0.03}$ & 14 & - & - & - \\
\hline Aude & $\% \mathrm{POC}=17.1 \mathrm{TSM}^{-0.5}$ & 14 & 0.9 & $710^{-6}$ & 0.06 \\
\hline Têt & $\% \mathrm{POC}=17.1 \mathrm{TSM}^{-0.3}$ & 14 & 0.5 & 0.0040 & 0.04 \\
\hline Fluvià & $\% \mathrm{POC}=13.7 \mathrm{TSM}^{-0.2}$ & 14 & 0.5 & 0.0040 & 0.3 \\
\hline Ter & $\% \mathrm{POC}=7.7 \mathrm{TSM}^{-0.01}$ & 14 & - & - & - \\
\hline Tordera & $\% \mathrm{POC}=15.8 \mathrm{TSM}^{-0.3}$ & 14 & 0.5 & 0.0040 & 0.01 \\
\hline PN vs. TSM & & & & & PN Flux \\
\hline Rhône & $\% \mathrm{PN}=1.5 \mathrm{TSM}^{-0.4}$ & 14 & 0.9 & $5.810^{-8}$ & 0.8 \\
\hline Hérault & $\% \mathrm{PN}=2.8 \mathrm{TSM}^{-0.5}$ & 14 & 0.3 & 0.04 & 0.009 \\
\hline Orb & $\% \mathrm{PN}=1.6 \mathrm{TSM}^{0.01}$ & 14 & - & - & - \\
\hline Aude & $\% \mathrm{PN}=4.6 \mathrm{TSM}^{-0.7}$ & 14 & 0.8 & $710^{-6}$ & 0.01 \\
\hline Têt & $\% \mathrm{PN}=3.1 \mathrm{TSM}^{-0.3}$ & 14 & 0.4 & 0.01 & 0.008 \\
\hline Fluvià & $\% \mathrm{PN}=1.9 \mathrm{TSM}^{-0.2}$ & 14 & 0.4 & 0.01 & 0.04 \\
\hline Ter & $\% \mathrm{PN}=1.0 \mathrm{TSM}^{-0.04}$ & 14 & - & - & - \\
\hline Tordera & $\% \mathrm{PN}=2.3 \mathrm{TSM}^{-0.3}$ & 14 & 0.4 & 0.01 & 0.001 \\
\hline
\end{tabular}

the sediments accumulated during low water flow periods (Sanchez-Vidal et al., 2013). In order to elucidate the relationship between water discharges and TSM, a sediment rating curve was established. The most commonly used is a power function with the standard form TSM $=a \times Q^{b}$, where $a$ and $b$ are regression coefficients (Asselman, 2000). The sediment rating curve shows a good correlation between log TSM and $\log Q$ in the Rhône River $\left(R^{2}=0.8\right)$ (Fig. 5), and relatively poorer in coastal rivers $\left(0.3<R^{2}<0.7\right)$ (Fig. 5). It should be noted that the Orb and Aude rivers do not have any correlation between $Q$ and TSM, as found by Liquete et al. (2009) in several coastal rivers flowing into the Catalan margin. Therefore, the use of a sediment rating curve to estimate TSM in the Rhône River is relatively accurate, whereas caution is needed for the coastal rivers. This is probably caused by two main factors: first, the strong natural temporal variability of the water flow. Brooks et al. (2003) reported that the rivers with flash flood events may take years to re- cover their original sediment curve. Second, the high impact of anthropogenic activities, such as dam constructions and water extractions for irrigation, which are very efficient filters for particulate matter (Meybeck and Vörösmarty, 2005), can alter the natural functioning of coastal rivers in terms of sediment transport (Liquete, 2008; Ludwig et al., 2009). For many fluvial systems the impact of dam constructions has been documented, which intercept half of the water discharge, store at least $30 \%$ of sediment fluxes (in major fluvial systems) and produce variations in the composition of suspended material (Meybeck and Vörösmarty, 2005; Syvitski et al., 2005). On the other hand, fluvial systems affected by irrigation, sometimes associated with water diversion from one basin to another, have much lower transport potential than under natural conditions (Meybeck and Vörösmarty, 2005).

The mechanism that controls the export of riverine POM is the riverine sediment load (Meybeck, 1982, Ludwig et al., 1996). The POC and PN contents of the TSM (in percentage) 

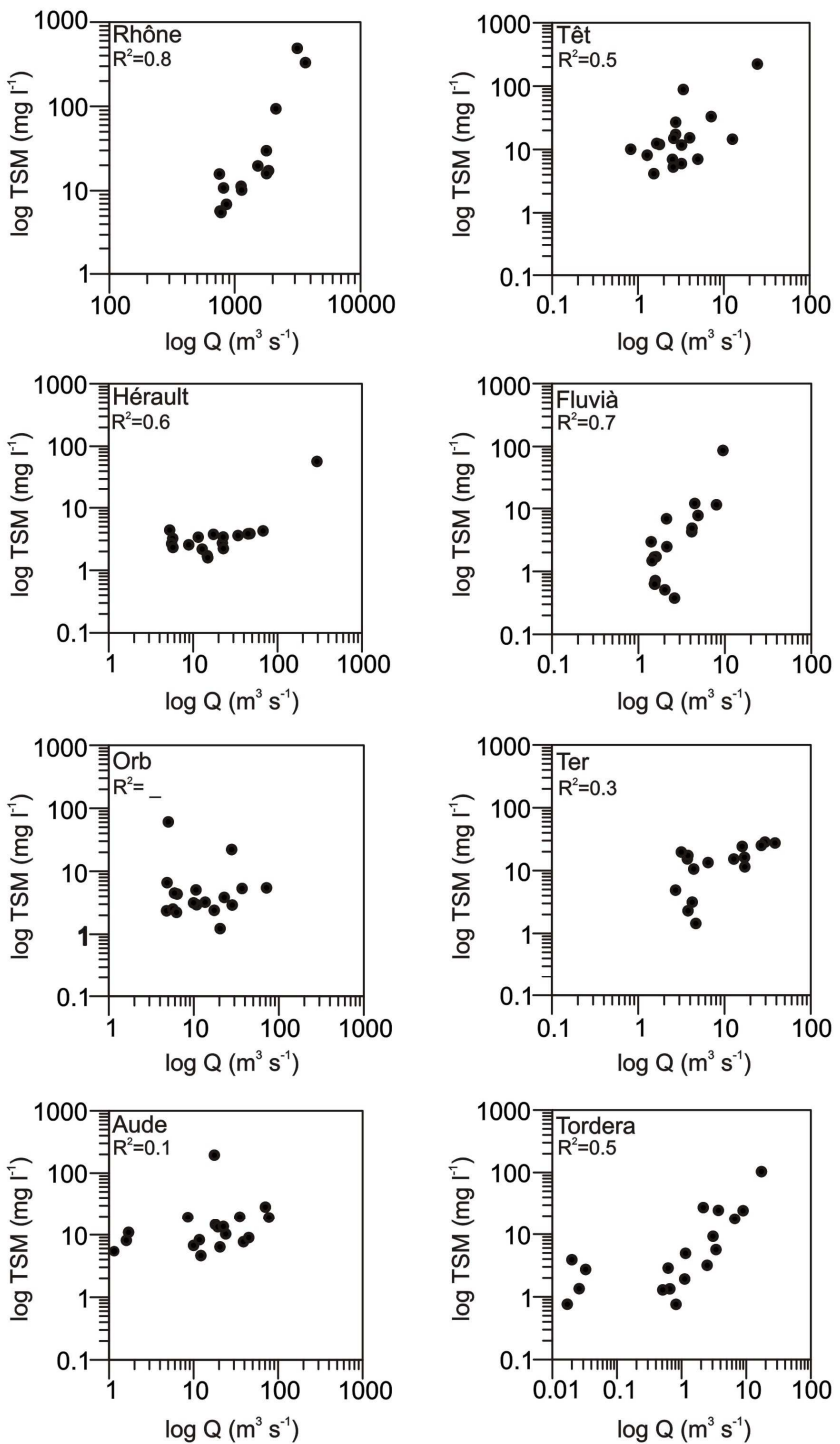

Fig. 5. Logarithmic plot between total suspended matter (TSM) concentration and average daily water discharge $(Q)$ with $R^{2}$ values obtained using the sediment rating curve: $\mathrm{TSM}=a \times Q^{b}$, where $a$ and $b$ are regression coefficients.

are usually highly variable in world rivers, ranging from 0.3 to $37 \%$ (Ittekkot and Arain 1986; Cauwet et al., 1990; Martin-Mousset et al.,1997) and from 0.1 to $1.3 \%$ (Malcolm and Durum, 1976; Meybeck, 1982), respectively. As we are also dealing with small coastal rivers, less turbid but enriched in OM compared to large rivers, our study presents a wider range of values (from 1.1 to $23.5 \%$ for POC and 0.1 to $4.6 \%$ for PN) than those of large worlds rivers. In order to prove the relationship between \% POC and TSM and \%PN and TSM in studied rivers, the power functions $\% \mathrm{POC}$ and $\% \mathrm{PN}=a \times \mathrm{TSM}^{b}$ have been also established.

The inverse relationship between \%POC and TSM and $\% \mathrm{PN}$ and TSM obtained in most of sampled rivers (Figs. 6
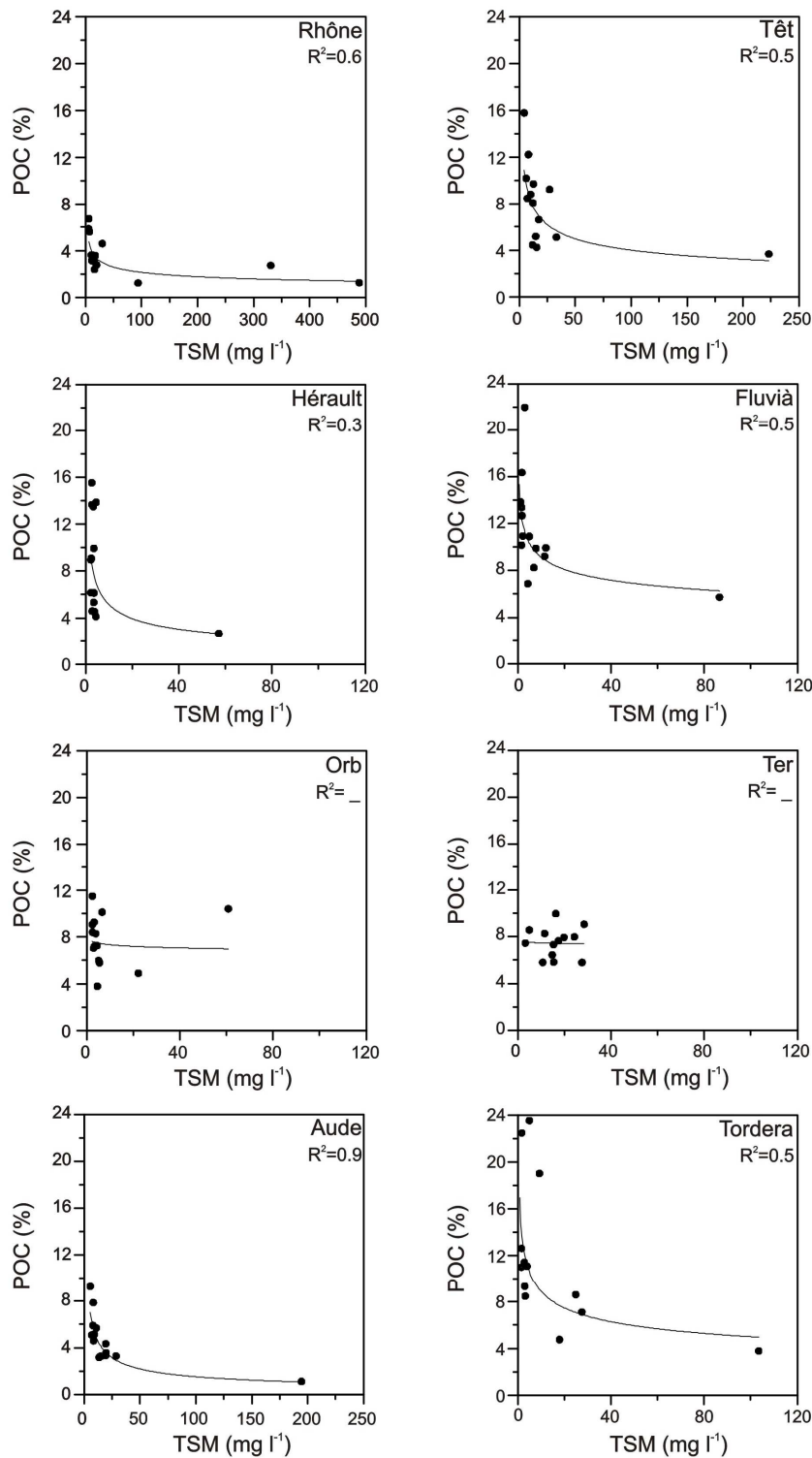

Fig. 6. Relationships between total suspended matter (TSM) concentration and particulate organic carbon (POC) contents (in percentage) with $R^{2}$ values obtained using the power equation: POC \% $=a \times \mathrm{TSM}^{b}$, where $a$ and $b$ are regression coefficients.

and 7) suggests dilution of the riverine POC and PN by the mineral matter resuspended from the riverbed during flash flood events. When the intensity of rainfall exceeds the infiltration rate, the soil surface becomes saturated in water and the eroded surface material is transported into streams and rivers. In Mediterranean coastal watersheds, soils dry out during periods of limited rainfall and heavier rainfall results in greater and more rapid runoff, thereby increasing the soil erosion (Nadeu et al., 2012). In addition, during events of high $Q$ and TSM the in situ primary production of POC and $\mathrm{PN}$ by riverine phytoplankton is reduced because of the 

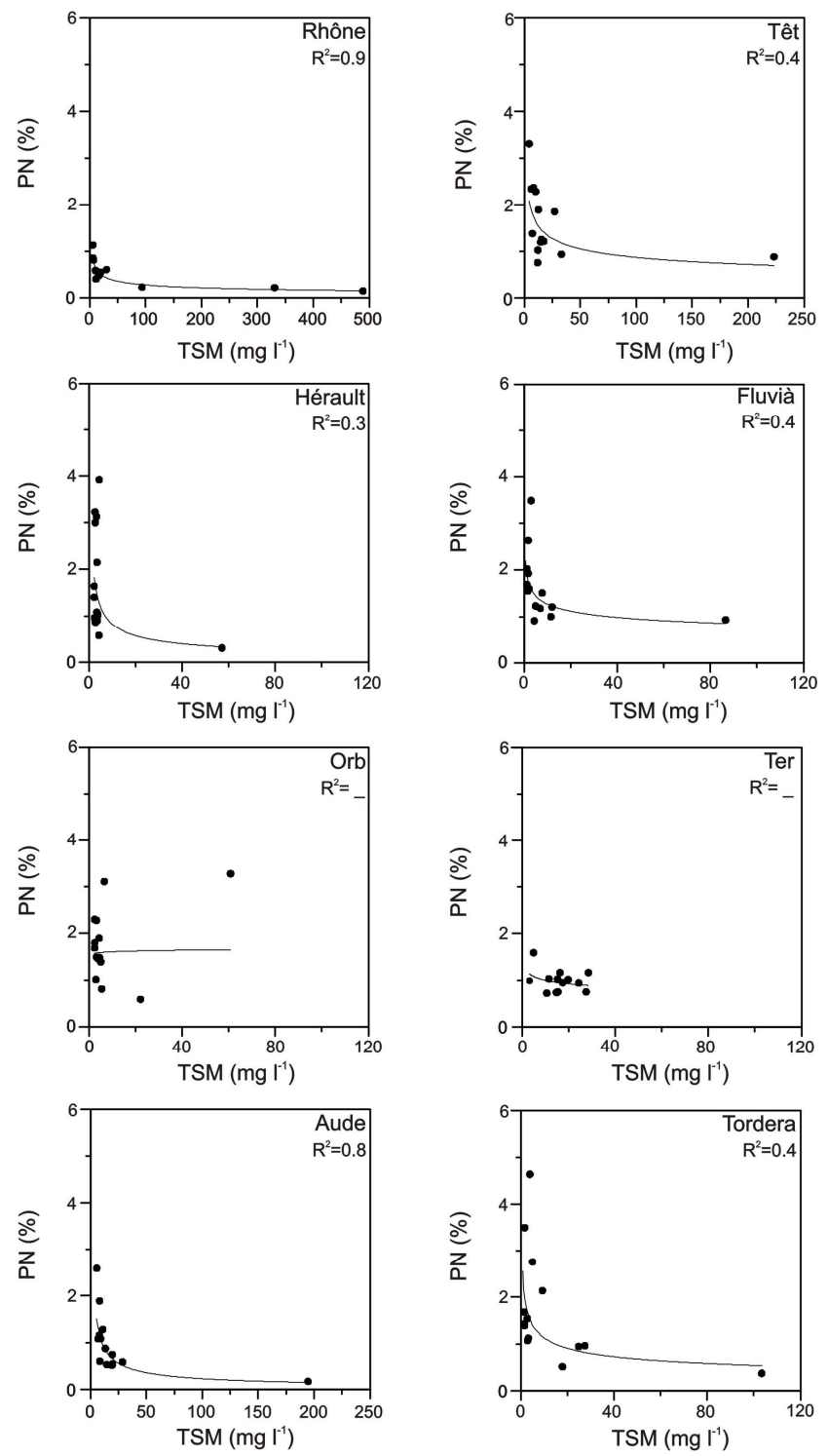

Fig. 7. Relationships between total suspended matter (TSM) and particulate nitrogen (PN) contents (in percentage) with $\mathrm{R}^{2}$ values obtained using this equation: $\mathrm{PN} \%=a \times \mathrm{TSM}^{b}$, where $a$ and $b$ are regression coefficients.

high turbidity and the low availability of light in river waters (Ludwig et al., 1996; Ni et al., 2008).

In contrast, the suspended material of coastal rivers was enriched in POC (from 9.3 to $23.5 \%$ ) and PN (from 1.6 to $4.6 \%$ ) during low water stages when TSM concentrations were low $\left(<5.4 \mathrm{mg} \mathrm{L}^{-1}\right)$. In this case photosynthesis can be an important contributor to POC and PN in low turbidity waters ( $\mathrm{Ni}$ et al., 2008). The calm and stagnant waters in coastal rivers, associated with high water temperature, likely favour the proliferation of freshwater phytoplankton. In the Rhône River, the mean TSM content is about 5 times higher than in coastal rivers. This high turbidity attenuates the photosynthetically available radiation (PAR) by producing a "shadow" effect. Harmelin-Vivien et al. (2010) found that the autochthonous phytoplankton in the downstream part of the Rhône River accounted on average for only $10 \%$ of the POM. For that reason, suspended particles of coastal rivers seem to be particularly more enriched in POM than the Rhône River (Table 2, Figs. 6 and 7).

Besides having a critical effect on the suspended sediment transport, river damming may also be responsible for the poor relationship between \%POC and TSM and \%PN and TSM in the Orb and Ter rivers (Figs. 6 and 7). Therefore, trapping of sediments by dams may also cause a decrease of POC and PN transport from the terrestrial to the marine environments (Sanchez-Vidal et al., 2013).

The amounts of TSM, POC and PN delivered annually (2008-2009) by the studied rivers have been estimated using the above mentioned power functions and the daily $Q$ data (Table 3). It is important to note that these fluxes are only calculated in rivers with a statistically significant $\mathrm{p}$ value $(p<0.05)$. As have all the previous studies performed on Mediterranean Rivers, we assumed that most of the freshwater particulate material is discharged into the microtidal sea (Cauwet et al., 1990; Sempere et al., 2000; Ludwig et al., 2003, Garcia-Esteves, 2005) and deposited and degraded in their marine prodeltas (e.g. Miserocchi et al., 2007; Cathalot et al., 2013). The lack of estuaries formed by tidal waves and characterized by large marine intrusions explain why studies on river inputs into the Mediterranean Sea consider the mouth as the boundary between fresh and saltwater though the wind direction and the freshwater runoff may affect this boundary as well. We found that the Rhône River delivered $2.8 \times 10^{6} \mathrm{t} \mathrm{yr}^{-1}$ of TSM, $5.8 \times 10^{4} \mathrm{tyr}^{-1}$ of POC and $0.8 \times 10^{4} \mathrm{tyr}^{-1}$ of PN while the sum of the studied coastal rivers discharged $0.1 \times 10^{6} \mathrm{tyr}^{-1}$ of TSM, $0.6 \times 10^{4} \mathrm{t} \mathrm{yr}^{-1}$ of POC and $0.1 \times 10^{4} \mathrm{tyr}^{-1}$ of PN. Thus, coastal rivers accounted for approximately $5 \%$ (TSM) and $10 \%$ (POC and PN) of the Rhône River fluxes. This relative contribution of coastal rivers compared to a large river should be considered as the minimum contribution, owing to the lack of some small coastal rivers (e.g. Tech River) and Mediterranean lagoons receiving small rivers. Our estimations for the Rhône River match those found by Cauwet et al. (1990) for the period 1986-1987 $\left(2.8 \times 10^{6} \mathrm{t}\right.$ $\mathrm{TSM} \mathrm{yr}^{-1}$ and $7.9 \times 10^{4} \mathrm{t} \mathrm{POC} \mathrm{yr}^{-1}$ ).

It is important to note that both studies were carried out during dry periods, as our $Q$ means were lower than the long-term mean of the Rhône River $\left(1710 \mathrm{~m}^{3} \mathrm{~s}^{-1}\right)$. In contrast, Sempéré et al. (2000) reported for 1987-1996 higher TSM and POC fluxes $\left(9.9 \times 10^{6} \mathrm{tyr}^{-1}\right.$ and $19.2 \times 10^{4} \mathrm{t} \mathrm{yr}^{-1}$, respectively) than in this study. During their $10 \mathrm{yr}$ survey more than 15 flood events over $5000 \mathrm{~m}^{3} \mathrm{~s}^{-1}$ were recorded, whereas no similar peaks were found during years 2008 2009 nor since December 2003. The highest reported TSM flux $\left(31 \times 10^{6} \mathrm{t} \mathrm{yr}^{-1}\right)$ for the Rhône River was calculated before the building of dams (Milliman and Syvitski, 1992). 

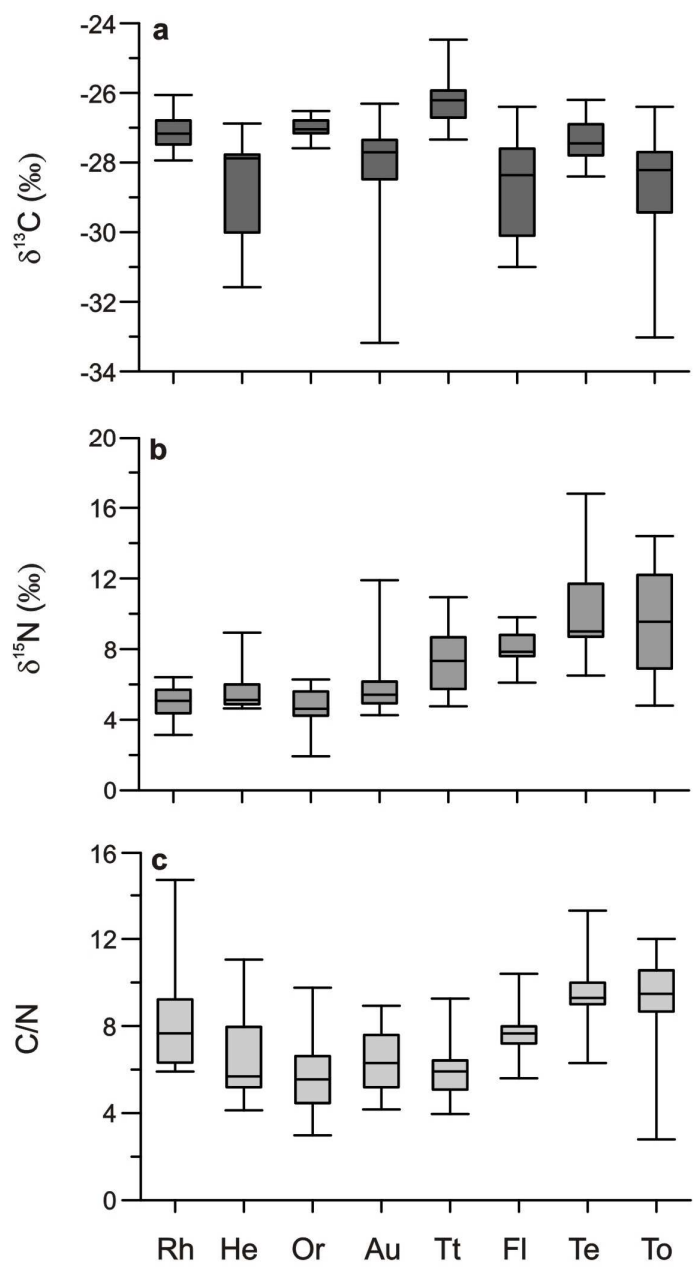

Fig. 8. Spatial variations of the stable isotopes $\delta^{13} \mathrm{C}$ (a) and $\delta^{15} \mathrm{~N}$ (b) and C/ N ratio (c) from November 2008 to December 2009. The box plot shows the extreme values, the quartiles and the mean value of each river.

Rh: Rhône, He: Hérault, Or: Orb, Au: Aude, Tt: Têt, Fl: Fluvià, Te: Ter and To: Tordera.

These dam constructions have had a major impact on the overall sediment transport to the Mediterranean Sea. The most striking example is the Ebro River where the recent sediment flux $\left(0.092 \times 10^{6} \mathrm{t} \mathrm{yr}^{-1}\right)$ represents less than $1 \%$ of what was transported before the period of dam constructions (Tena et al., 2011). In comparison, two other French rivers (Garonne River and Dordogne River) flowing into the Gironde estuary exhibited TSM $\left(2.4 \times 10^{6} \mathrm{t} \mathrm{yr}^{-1}\right.$ and $0.8 \times 10^{6} \mathrm{t} \mathrm{yr}^{-1}$, respectively) and POC $\left(7.2 \times 10^{4} \mathrm{t} \mathrm{yr}^{-1}\right.$ and $4.7 \times 10^{4} \mathrm{tyr}^{-1}$, respectively) fluxes, varying within the same ranges as our Rhône River fluxes (Schäfer et al., 2002).

Pont et al. (2002) estimated that Rhône floods with return period higher than one year accounted for $77 \%$ of the TSM export. During our study (2008-2009), this flood ( $>1 \mathrm{yr}$ return period) contribution to the TSM flux, as well as to the POC and PN fluxes, were varying around a low
$40 \%$ as no floods over $5000 \mathrm{~m}^{3} \mathrm{~s}^{-1}$ were recorded. Comparisons can also be done on the most studied of the coastal rivers, the Têt River. Our annual TSM and POC flux estimations ( $8339 \mathrm{t} \mathrm{TSM} \mathrm{yr}^{-1}$ and $393 \mathrm{t} \mathrm{POC} \mathrm{yr}^{-1}$ ) exhibit significantly lower fluxes than fluxes (16046 tTSM yr ${ }^{-1}$ and

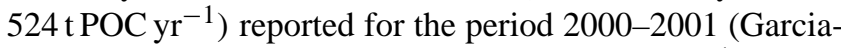
Esteves, 2005) and than TSM fluxes $\left(50000 \mathrm{t} \mathrm{yr}^{-1}\right)$ calculated for the 1980-1999 period (Serrat et al., 2001). These latter authors revealed an extreme variability between annual water and sediment fluxes. According to Serrat et al. (2001), more than $50 \%$ of the overall sediment transported for the $20 \mathrm{yr}$ of investigation was discharged during only 13 days of exceptional floods. This contribution reached up to 80-90\% when including moderate floods. In this study, we found the lowest contribution $(18 \%)$ of floods ( $>1 \mathrm{yr}$ ) on the TSM export of the Ter River, which is strongly affected by dams and reservoirs trapping sediments. On the other hand, more than $95 \%$ of the TSM, POC and PN exports occurred during a unique but significant flood in December 2008 (return period of $3 \mathrm{yr}$ ) of the Fluvià River. It is evident that estimates of TSM, POC and PN fluxes from coastal rivers depend on whether the survey has been performed during dry, normal or humid years.

\subsection{Sources of POM transferred to the NW Mediterranean Sea}

Riverine POM is habitually composed of a mixture of organic matter derived from autochthonous aquatic production and allochthonous terrestrial detritus of various origins (Maksymowska et al., 2000; Finlay and Kendall 2007; Harmelin-Vivien et al., 2010), which include vascular plants, soil-derived organic matter, freshwater algae and anthropogenic inputs. The proportions of each source vary according to the size of watershed, meteorological factors (such as the occurrence of storms) and land use. In the Mediterranean basins the natural forest and grassland are dominated by $\mathrm{C} 3$ plants (mainly higher plants), although a minor contribution of invasive $\mathrm{C} 4$ plants (cactus and herbs) are found in some areas of the Mediterranean coast (Sage et al., 1999; Novara et al., 2011). C3 plants are characterized by $\delta^{13} \mathrm{C}$ values from $-25 \%$ to $-28 \%$ (Hedges et al., 1997), $\delta^{15} \mathrm{~N}$ values from $3 \%$ to $7 \%$ (Ongrinc et al., 2008) and $\mathrm{C} / \mathrm{N}$ values from 20 to 100 (Countway et al., 2007). Accordingly, the soil organic matter has typically $\delta^{13} \mathrm{C}$ values of $-24 \%$ o to $-29 \%$ o (Ogrinc et al., 2008), which indeed reflect the plants growing on it. $\delta^{15} \mathrm{~N}$ values of soil organic matter range from $2.6 \%$ o to $6.4 \%$ (McCallister et al., 2004) and the $\mathrm{C} / \mathrm{N}$ found in soils range from 8 to 15 (McCallister et al., 2004). Concerning algae sources, photosynthesis by freshwater phytoplankton generates $\mathrm{POM}$ with ${ }^{13} \mathrm{C}$ values mostly ranging from $-25 \%$ o to $-30 \%$ o (Boutton, 1991; Cloern et al., 2002), though several $\delta^{13} \mathrm{C}$ ratios lower than $-30 \%$ o have been encountered in rivers (e.g. Hellings et al., 1999; Cloern et al., 2002). 
$\delta^{15} \mathrm{~N}$ values range from 5 to $8 \%$ (Cloern et al., 2002; McCallister et al., 2004) and $\mathrm{C} / \mathrm{N}$ ratios from 4 to 10 (Meyers, 1994, Cloern et al., 2002). Therefore, $\delta^{13} \mathrm{C}$ and $\delta^{15} \mathrm{~N}$ of suspended POM as well as $\mathrm{C} / \mathrm{N}$ ratios will allow us to determine the source of organic matter in all studied rivers.

$\delta^{13} \mathrm{C}$ and $\delta^{15} \mathrm{~N}$ mean values found in TSM in the Rhône River are $-27.1 \pm 0.6 \%$ and $4.9 \pm 1 \%$, respectively, which are within the range of those by Harmelin-Vivien et al. (2010) in $2004\left(\delta^{13} \mathrm{C}:-26.6 \pm 1.2 \% \circ\right.$ and $\left.\delta^{15} \mathrm{~N}: 5.7 \pm 1.8 \% \circ\right)$ and $2005\left(\delta^{13} \mathrm{C}:-27.4 \pm 1.4 \%\right.$ and $\left.\delta^{15} \mathrm{~N}: 4.8 \pm 1 \% o\right)$. These values are also similar to those found by Bănaru et al. (2007) in the Danube River, the second largest river in Europe $\left(\delta^{13} \mathrm{C}\right.$ : $-27.5 \pm 0.9 \%$ and $\delta^{15} \mathrm{~N}: 4.9 \pm 1.5 \%$ ). Interestingly, $\delta^{15} \mathrm{~N}$ of TSM in the Têt River increased significantly from 2006 $\left(\delta^{15} \mathrm{~N}\right.$ of $1.9 \pm 1.2 \%$, Kerhervé, personal communication, $2007)$ to 2008 ( $\delta^{15} \mathrm{~N}$ of $7.5 \pm 1.9 \%$, this study). As will be discussed later, this isotopic shift is probably related to the construction in 2008 of a new wastewater treatment plant (WWTP) for the district of Perpignan city.

The isotopic composition of POC and PN as well as the $\mathrm{C} / \mathrm{N}$ ratio were highly variable during the investigated year and between rivers (Fig. 8a, b, c), which suggest that different sources of POM dominate during the survey. The $\delta^{13} \mathrm{C}$ values were specially variable in the Hérault, Aude, Fluvià and Tordera rivers, while rather constant values were found throughout the survey in the Rhône, Orb, Têt and Ter rivers (Fig. 8a). This discrepancy between rivers is due to the ${ }^{13} \mathrm{C}$-depleted values $(-29.4$ to $-33.2 \%$ ) recorded during summer and early autumn months (July to October 2009) in the Hérault and Aude rivers, as well as the Tordera River (also in November and December 2008). During those months very low water discharges and high water temperatures (up to $25^{\circ} \mathrm{C}$ ) were recorded. These conditions may have favoured the proliferation of phytoplankton, thus increasing in POC contents (up to 15.5, 9.3 and 22.4\% in the Hérault Aude and Tordera rivers, respectively) and decreasing the $\delta^{13} \mathrm{C}$ ratio $(\sim-30 \%)$. Indeed, nutrients are large enough in warm and stagnant waters from the downstream part (the most human influenced area) of coastal rivers to provoke algae productions (Garcia-Esteves 2005, Ludwig et al., 2003). The ${ }^{13} \mathrm{C}$-depleted POM produced in such conditions is mainly attributed to high contents of ${ }^{13} \mathrm{C}$ depleted DIC produced by the mineralization of terrestrial and freshwater13C-depleted POM (Cloern et al., 2002; Liu et al., 2007).

The rivers with the smaller watersheds (Fluvià and Tordera rivers), which are torrential in their character, exhibited a different temporal pattern in the origin of the $\mathrm{POM}$, with ${ }^{13} \mathrm{C}$ depleted values found in winter (Fluvià River) and summer (Tordera River). Thus, suspended particles during the long periods of low water discharges and low TSM concentrations are enriched in POC derived from autochthonous primary production $\left(\delta^{13} \mathrm{C}\right.$ from -33 to $-29.4 \%$ ) even in winter. In contrast, high water discharges, produced by rainstorm events or snowmelt, trigger a fast increase of TSM, thus re- ducing the POC contents (because of the dilution effect and lowered primary production) and showing enriched $-{ }^{13} \mathrm{C}$ values (from -28.1 to $-25 \%$ ) compared to low water stages. During these periods, when the TSM concentration is higher than $50 \mathrm{mg} \mathrm{L}^{-1}$, an averaged $\delta^{13} \mathrm{C}$ value of $26.3 \pm 0.4 \%$ is calculated in the Rhône River, and coastal rivers show an averaged $\delta^{13} \mathrm{C}$ of $-26.9 \pm 1.2 \%$. This POM is likely originated from eroded soils and their $\mathrm{C}$ isotopic values vary within the same range (around $-25.8 \%$ ) as compared to surface soils from a small Mediterranean watershed in SE Spain (Nadeu et al., 2012). The soil end-member of coastal rivers exhibits a lower averaged $\delta^{13} \mathrm{C}$ value than that of the Rhône River. This difference may be explained by the importance of natural vegetation (more than $75 \%$ of the total areas) in watersheds of coastal rivers (Lespinas et al., 2010). In the Mediterranean region, plant remains are deposited and accumulated on the ground during long drought periods before they are transported into streams and rivers.

The $\delta^{15} \mathrm{~N}$ values of POM show a clear difference between studied rivers. POM in rivers draining the Alps and the Central Massif show rather constant $\delta^{15} \mathrm{~N}$ values (mean $\delta^{15} \mathrm{~N}$ of $5.4 \pm 1.4 \%$ ) while POM in rivers draining the Pyrenees and Montseny Massif exhibit the highest and most variable $\delta^{15} \mathrm{~N}$ ratios (mean $\delta^{15} \mathrm{~N}$ of $9.2 \pm 2.6 \%$ ), except the Fluvià River, which is more constant (mean $\delta^{15} \mathrm{~N}$ of $8.1 \pm 1 \%$ ) (Fig. 8b). The maximum $\delta^{15} \mathrm{~N}$ values were obtained in the Têt, Ter and Tordera rivers (10.9, 16.8 and $14.4 \%$, respectively), coinciding with the lowest $Q$ as well as the highest POC and PN contents. This $\delta^{15} \mathrm{~N}$ enrichment during low water discharge is probably influenced by human activities and the denitrification processes occurring in WWTPs. The dissolved inorganic nitrogen (DIN) present in sewage effluents is usually enriched with ${ }^{15} \mathrm{~N}$ (Bottcher et al.,1990; Kendall et al., 2001; Cole et al., 2006). During low water stages the contribution of sewage inputs increases (Garcia-Esteves, 2005) and eutrophication processes such as denitrification can occur in the river as in the water treatment plants. This process removes ${ }^{14} \mathrm{~N}$-nitrate at a faster rate than ${ }^{15} \mathrm{~N}$-nitrate because ${ }^{14} \mathrm{~N}$ is lighter and easier to metabolize (Heaton, 1986). The remaining nitrate in sewage effluent is therefore ${ }^{15} \mathrm{~N}$ enriched and organic nitrogen compounds produced by phytoplankton cells will also tend to become enriched in ${ }^{15} \mathrm{~N}$ (Costanzo et al., 2005), with $\delta^{15} \mathrm{~N}$ values reaching up 10 or $20 \%$ in polluted rivers (Kreitler et al., 1978; Macko and Ostrom, 1994; McClelland and Valiela, 1998). Therefore, the ${ }^{15} \mathrm{~N}$-enriched POM in Têt, Ter and Tordera rivers likely reflects the importance of urban activities in the lowest part of their watersheds.

\section{Conclusions}

This study has allowed us to simultaneously assess for the first time the variations in the quantity and origin of the POM discharged by eight rivers into the NW Mediterranean Sea 
and their relation to the water flows. Our main conclusions are as follows.

1. The large Rhône River is characterized by high and relatively constant water flow and TSM concentrations, in contrast to coastal rivers characterized by long periods of low water stages and eutrophication processes, as well as by ephemeral high flows produced by rainstorm events. Coastal rivers draining the Central Massif (Hérault, Orb and Aude rivers) are more impacted by Cévenol events triggered by S-SE winds, whereas coastal rivers draining the Pyrenees and the Montseny Massif (Têt, Fluvià, Ter and Tordera rivers) are more affected by Llevantada events triggered by E$\mathrm{NE}$ winds. These rainstorms produce a fast increase of $Q$, which removes the sediments accumulated during the low water flow periods, thus increasing the TSM concentration in coastal rivers.

2. This study shows that riverine inputs to the NW Mediterranean are not homogeneous throughout the survey in terms of quality of organic matter discharged from land to sea.

- The coastal rivers transport suspended particles that are enriched in organic compounds (POC $\sim 8.5 \%$ and $\mathrm{PN} \sim 1.5 \%$ ) compared to the Rhône River material ( $\mathrm{POC} \sim 3.6 \%$ and $\mathrm{PN} \sim 0.5 \%$ ). This discrepancy reflects a more pronounced eutrophication of waters in coastal rivers that is likely due to the reduction of the water discharge for all studied rivers, as observed throughout Mediterranean rivers over the last 40 years by Ludwig et al. (2003). This decrease of $Q$ is likely directly related to the temperature increase (mean annual: $1.5^{\circ} \mathrm{C}$ during $40 \mathrm{yr}$ period) as well as the increasing use of water for human activities (Lespinas et al., 2010). The decrease of precipitation during certain periods of the year in the upstream watersheds can also affect the water flows and favour the eutrophication of waters in coastal rivers.

- The isotopic ratios $\left(\delta^{13} \mathrm{C}\right.$ and $\left.\delta^{15} \mathrm{~N}\right)$ of POM reflect a mixture of terrestrial (plants remains and soils) and algae (freshwater phytoplankton) sources, with different proportions according to the river and the water flow. The coastal rivers, characterized by long periods of low water stages, are often places where eutrophication processes enhance the production of freshwater phytoplankton, as indicated by high POC and PN contents as well as ${ }^{13} \mathrm{C}$-depleted $(\sim-30 \%)$ and ${ }^{15} \mathrm{~N}$-enriched $(>8 \%$ ) values. During high flows (rainfalls and snowmelt), the isotopic ratios $\left(\delta^{13} \mathrm{C}\right.$ and $\left.\delta^{15} \mathrm{~N}\right)$ of coastal rivers $(-26.9$ and $4.7 \%$, respectively) tend to isotopic values of the
Rhône River (-26.3 and 3.8\%o). These ratios express an organic-poor material mainly associated with soils and plant remains.

Acknowledgements. We thank C. Liquete for providing Fig. 1, and Compagnie Nationale du Rhône, Hydro France and Agència Catalana de L'Aigua for providing hydrological data. We also thank all people involved in the water sampling of the French rivers (D. Aubert, J. Carbonne, C. Sotin, N. Delsaut and D. M'PeletBoukidi) and the two referees for their valuable comments. This research has been supported by the PERSEUS (FP7OCEAN-2011-3-287600), GRACCIE-CONSOLIDER(CSD200700067), and ANR-CHACCRA (ANRVULN-06-001-01) research projects, and the Zone Atelier ORME network (CNRS). We also received support from Catalan Government through a Grups de Recerca Consolidats grant (2009-SGR-1305).

Edited by: S. Bouillon

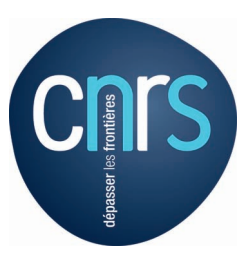

The publication of this article is financed by CNRS-INSU.

\section{References}

Agència Catalana de L'Aigua (ACA), available at: http://www. gencat.cat/aca/ (last access: 3 July 2013), 2013.

Asselman, N.: Fitting and interpretation of sediment rating curves, J. Hydrol., 234, 228-248, 2000.

Aucour, A. M., Sheppard, S. M. F., and Savoye R.: $\delta^{13}$ C of fluvial mollusc shells (Rhône River): a proxy for dissolved inorganic carbon?, Limnol. Oceanogr., 48, 2186-2193, 2003.

Bănaru, D., Harmelin-Vivien, M., Gomoiu, M. T., and Onciu, T. M.: Influence of the Danube River inputs on $\mathrm{C}$ and $\mathrm{N}$ stable isotope ratios of the Romanian coastal waters and sediment (Black Sea), Mar. Pollut. Bull., 54, 1385-1394, 2007.

Böttcher, J., Strebel, O., Voerkelius, S., and Schmidt, H. L.: Using isotope fractionation of nitrate-nitrogen and nitrate-oxygen for evaluation of microbial denitrification in a sandy aquifer, J. Hydrol., 114, 413-424, 1990.

Bourgeois, S., Pruski, A. M., Sun, M.-Y., Buscail, R., Lantoine, F., Kerhervé, P., Vétion, G., Rivière, B., and Charles, F.: Distribution and lability of land-derived organic matter in the surface sediments of the Rhône prodelta and the adjacent shelf (Mediterranean Sea, France): a multi proxy study, Biogeosciences, 8, 3107-3125, doi:10.5194/bg-8-3107-2011, 2011.

Bourrin, F., Friend, P. L., Amos, C. L., Manca, E., Ulses, C., Palanques, A., Durrieu de Madron, X., and Thomson, C. E. L.: Sediment dispersal from a typical Mediterranean flood: The Têt River, Gulf of Lions, Cont. Shelf Res., 28, 1895-1910, 2008.

Boutton, T. W.: Stable carbon isotope ratios of natural materials, I. Sample preparation and mass spectrometric analysis, in: Carbon Isotope Techniques, edited by: Coleman, D. C. and Fry, B., Academic Press, New York, 155-171, 1991. 
Brooks, K. N., Folliott, P. F., Gregersen, H. M., and DeBano, L. F.: Sediment yield and channel processes, in: Hydrology and the management of watersheds, 3, Iowa State Press, Iowa, 211-230, 2003.

Cathalot, C., Rabouille, C., Pastor, L., Deflandre, B., Viollier, E., Buscail, R., Grémare, A., Treignier, C., and Pruski, A.: Temporal variability of carbon recycling in coastal sediments influenced by rivers: assessing the impact of flood inputs in the Rhône River prodelta, Biogeosciences, 7, 1187-1205, doi:10.5194/bg7-1187-2010, 2010.

Cathalot, C., Rabouille, C., Tisnérat-Laborde, N., Toussaint, F., Kerhervé, P., Buscail, R. , Loftis, K., Sun, M-Y., Tronczynski, J., Azoury, S., Lansard, B., Treignier C., Pastor, L. and Tesi, T.: The fate of river organic carbon in coastal areas: a study in the Rhône River delta using multiple isotopic $\left(\delta^{13} \mathrm{C}, \Delta^{14} \mathrm{C}\right)$ and organic tracers, Geochim. Cosmochim. Acta, 118, 33-55, 2013.

Cauwet, G., Gadel, F., Souza Sierra, M. M., Donard, O., and Ewald, M.: Contribution of the Rhône River to organic carbon inputs to the northwestern Mediterranean Sea, Cont. Shelf Res., 10, 10251037, 1990.

Chen, Z., Li, J., Shen, H., and Zhanghua, W.: Yangtze River of China: historical analysis of discharge variability and sediment flux, Geomorphology, 41, 77-91, 2001.

Cloern, J. E., Canuel, E. A., and Harris, D.: Stable carbon and nitrogen isotope composition of aquatic and terrestrial plants of the San Francisco Bay estuarine system, Limnol. Oceanogr., 47, 713-729, 2002.

Cole M. L., Kroeger K. D., McClelland, J. W., and Valiela, I.: Effects of watershed land use on nitrogen concentrations and $\delta^{15}$ nitrogen in groundwater, Biogeochemistry, 77, 199-215, 2006.

Compagnie Nationale du Rhône, available at: http://www. inforhone.fr/inforhone/FR/Commun/index.aspx (last access: 14 May 2013), 2013.

Company, J. B., Puig, P., Sardà, F., Palanques, A., Latasa, M., and Scharek, R.: Climate Influence on Deep Sea Populations, PLoSONE, 3, e1431, doi:10.1371/journal.pone.0001431, 2008

Costanzo, S. D., Udy, J., Longstaff, B., and Jones, A.: Using nitrogen stable isotope ratios $\left(\delta^{15} \mathrm{~N}\right)$ of macroalgae to determine the effectiveness of sewage upgrades: changes in the extent of sewage plumes over four years in Moreton Bay, Australia, Mar. Pollut. Bull., 51, 212-217, 2005.

Countway, R. E., Canuel, E. A., and Dickhut, R. M.: Sources of particulate organic matter in surface waters of the York River, VA estuary, Organ. Geochem., 38, 365-379, 2007.

Darnaude, A. M., Salen-Picard, C., Polunin, N. V. C., and HarmelinVivien, M.: Trophodynamic linkage between river runoff and coastal fishery yield elucidated by stable isotope data in the Gulf of Lions (NW Mediterranean), Oecologia, 138, 325-332, 2004.

Fabres, J., Calafat, A., Sanchez-Vidal, A., Canals, M., and Heussner, S.: Composition and spatio-temporal variability of particle fluxes in the Western Alboran Gyre, Mediterranean Sea, J. Mar. Syst., 33/34, 431-456, 2002.

Finlay, J. C. and Kendall, C.: Stable isotope tracing of temporal and spatial variability in organic matter sources to freshwater ecosystems, in: Stable Isotopes in Ecology and Environmental Science, edited by: Michener, R.H. and Lajtha, K., 551 Blackwell, Malden, MA, USA, 283-333, 2007.

Fontanier, C., Jorissen, F. J., Lansard, B., Mouret, A., Buscail, R., Schmidt, S., Kerhervé, P., Buron, F., Zaragosi, S., Hunault, G.,
Ernoult, E., Artero, C., Anschutz, P., and Rabouille, C.: Live foraminifera from the open slope between Grand Rhône and Petit Rhône canyons (Gulf of Lions, NW Mediterranean), Deep-Sea Res. Pt. I, 55, 1532-1553, 2008

Garcia-Esteves, J.: Géochimie d'un fleuve côtier Méditerranéen: la Têt en Roussillon. Origines et transferts de matières dissoutes et particulaires de la source jusqu'à la mer, Ph.D. thesis, University of Perpignan, France, 263 pp., 2005.

Garcia-Esteves, J., Ludwig, W., Kerhervé, P., Probst, J.-L., and Lespinas, F.: Predicting the impact of land use on the major element and nutrient fluxes in coastal Mediterranean rivers: the case of the Têt River (Southern France), Appl. Geochem., 22, 230248, 2007.

Gaume, E., Livet, M., Desbordes, M., and Villeneuve, J. P.: Hydrological analysis of the river Aude, France, flash ?ood on 12 and 13 November 1999, J. Hydrol., 286, 135-154, 2004.

Goodbred Jr., S. L. and Kuehl, S. A.: Enormous GangesBrahmaputra sediment discharge during strengthened early Holocene monsoon, Geology, 28, 1083-1086, 2000.

Harmelin-Vivien, M., Dierking, J., Bănaru, D., Fontaine, F., and Arlhac, D.: Seasonal variation in stable $\mathrm{C}$ and $\mathrm{N}$ isotope ratios of the Rhône River inputs to the Mediterranean Sea (2004-2005), Biogeochemistry, 100, 139-150, 2010.

Heaton, T. H. E.: Isotopic studies of nitrogen pollution in the hydrosphere and atmosphere: a review, Chem. Geol., 59, 87-102, 1986.

Hedges, J. I., Keil, R. G., and Benner, R.: What happens to terrestrial organic matter in the ocean?, Org. Geochem., 27, 195-212, 1997.

Hellings, L., Dehairs, F., Tackx, M., Keppens, E., and Baeyens, W.: Origin and fate of organic carbon in the freshwater part of the Scheldt estuary as traced by stable carbon isotope composition, Biogeochemistry 47, 167-186, 1999.

Hermand, R., Salen-Picard, C., Alliot, E., and Degiovanni, C.: Macrofaunal density, biomass and composition of estuarine sediments and their relationship to the river plume of the Rhône River (NW Mediterranean), Estuar. Coast. Shelf S., 79, 367-376, 2008

Hydro France, available at: http://www.hydro.eaufrance.fr/ ( last access: 26 May 2013), 2013.

Ibanez, C., Pont, D., and Pratt, N.: Characterization of the Ebre and Rhône estuaries: A basis for defining and classifying saltwedge estuaries, Limnol. Oceanogr., 42, 89-101, 1997.

Ittekkot, V. and Arain, R.: Nature of particulate organic matter in the river Indus, Pakistan, Geochim. Cosmochim. Acta, 50, 16431653, 1986.

Kendall, C., Silva, S. R., and Kelly, V. J.: Carbon and nitrogen isotopic compositions of particulate organic matter in four large river systems across the United States. Hydrol. Process, 15, 1301-1346, 2001.

Kreitler, C. W., Ragone, S., and Katz, B. G.: ${ }^{15} \mathrm{~N} /{ }^{14} \mathrm{~N}$ ratios of ground-water nitrate, Long Island, New York, Ground Water, 16, 404-409, 1978.

Kuehl, S. A., Levy, B. M., Moore, W. S., and Allison, M. A.: Subaqueous delta of the Ganges-Brahmaputra river system, Mar. Geol., 144, 81-96, 1997.

Lespinas, F., Ludwig,W., and Heussner, S.: Impact of recent climate change on the hydrology of coastal Mediterranean rivers in Southern France, Clim. Chang., 99, 425-456, 2010. 
Liquete, C.: La plataforma continental de Barcelona: Análisis "Source to sink" e impactos antropogénicos, PhD thesis, University of Barcelona, Spain, 276 pp., 2008.

Liquete, C., Canals, M., Ludwig, W., and Arnau, P.: Sediment discharge of the rivers of Catalonia, NE Spain, and the influence of human impacts, J. Hydrol., 366, 76-88, 2009.

Liu, J. P. and Milliman, J. D.: Reconsidering melt-water pulses 1A and 1B: global impacts of rapid sea-level rise, J. Ocean Univ. China, 3, 183-190, 2004.

Liu, J. P., Milliman, J. D., and Gao, S.: The Shandong mud wedge and post-glacial sediment accumulation in the Yellow Sea, GeoMar. Lett., 21, 212-218, 2002.

Liu, J. P, Xu, K. H, Li, A. C., Milliman, J. D., Velozzi, D. M., Xiao, S. B., and Yang Z. S.: Flux and fate of Yangtze River sediment delivered to the East China Sea, Geomorphology, 85, 208-224, 2007.

Liu, K. K., Kao, S. J., Wen, L. S., and Chen, K. L.: Carbon and nitrogen isotopic compositions of particulate organic matter and biogeochemical processes in the eutrophic Danshuei Estuary in northern Taiwan, Sci. Tot. Environ., 382, 103-120, 2007.

López-Moreno, J. I., Beniston, M., and García-Ruiz, J. M.: Environmental change and water management in the Pyrenees: facts and future perspectives for Mediterranean mountains, Global Planet. Change, 61, 300-312, 2008.

Ludwig, W. and Probst, J. -L.: River sediment discharge to the oceans: Present-day controls and global budgets, Am. J. Sci., 296, 265-295, 1998.

Ludwig, W., Probst, J. -L., and Kempe, S.: Predicting the oceanic input of organic carbon by continental erosion, Global Biogeochem. Cycles, 10, 23-41, 1996.

Ludwig, W., Meybeck, M., and Abousamra, F.: Riverine transport of water, sediments, and pollutants to the Mediterranean Sea, UNEP MAP Technical report Series 141, UNEP/MAP Athens, 2003.

Ludwig, W., Dumont, E., Meybeck, M., and Heussner, S.: A River discharges of water and nutrients to the Mediterranean and Black Sea: Major drivers for ecosystem changes during past and future decades, Prog. Oceanogr., 80, 199-217, 2009.

Macko, S. A. and Ostrom, N. E.: Sources of variation in the stable isotopic composition of plants, in: Stable isotopes in ecology, edited by: Lajtha, K. and Michener, R. H., Blackwell, 45-62, 1994.

Maksymowska, D., Richard, P., Piekarek-Jankowska, H., and Riera, P.: Chemical and isotopic composition of the organic matter sources in the Gulf of Gdansk (Southern Baltic Sea), Est. Coast. Shelf Sci., 51, 585-598, 2000.

Malcolm, R. L. and Durum, W. H.: Organic carbon and nitrogen concentration and annual organic carbon load for six selected rivers of the USA., US Geol. Survey Water-Supply Paper 1817-F, p. 21, 1976.

Margat, J.: L'eau dans le bassin méditerranéen, in: Association pour les espaces naturels, Paris, France, 1992.

Martin-Mousset, B., Croue, J. P., Lefebvre, E., and Legube, B.: Distribution et caractérisation de la matière organique dissoute d'eaux naturelles de surface, Water Res., 31, 541-553, 1997.

McCallister, S. L., Bauer J. E., Cherrier, J. E., and Ducklow, H. W.: Assessing sources and ages of organic matter supporting river and estuarine bacterial production: A multiple-isotope $\left(\Delta^{14} \mathrm{C}\right.$, $\delta^{13} \mathrm{C}$, and $\left.\delta^{15} \mathrm{~N}\right)$ approach, Limnol. Oceanogr., 49, 1687-1702, 2004.
McClelland, J. W. and Valiela, I.: Linking nitrogen in estuarine producers to land-derived sources, Limnol. Oceanogr., 43, 577-585, 1998.

Meybeck, M.: Carbon, nitrogen and phosphorus transport by world rivers, Am. J. Sci., 282, 401-450, 1982.

Meybeck, M. and Vörösmarty, C. J.: Fluvial filtering of land to ocean fluxes: from natural Holocene variations to Anthropocene, Comptes Rendus, 337, 107-123, 2005.

Meyers, P. A.: Preservation of elemental and isotopic source identification of sedimentary organic matter, Chem. Geol., 114, 289302, 1994.

Milliman, J. D.: Delivery and fate of fluvial water and sediment to the sea: a marine geologist's view of European rivers, Sci. Mar., $65,121-132,2001$

Milliman, J. D. and Syvitski, J. P. M.: Geomorphic/tectonic control of sediment discharge to the ocean: the importance of small mountainous rivers, J. Geol., 100, 525-544, 1992.

Miserocchi, S., Langone, L., and Tesi, T.: Content and isotopic composition of organic carbon within a flood layer in the Po River prodelta (Adriatic Sea). Cont. Shelf Res., 27, 338-358, 2007.

Nadeu, E., Berhe, A. A., de Vente, J., and Boix-Fayos, C.: Erosion, deposition and replacement of soil organic carbon in Mediterranean catchments: a geomorphological, isotopic and land use change approach, Biogeosciences, 9, 1099-1111, doi:10.5194/bg-9-1099-2012, 2012.

Ni, H-G., Lu, F. H., Luo, X-L., Tian, H-Y. andZeng, E-Y.: Riverine inputs of total organic carbon and suspended particulate matter from Pearl River Delta to the coastal ocean off South China, Mar. Pollut. Bull., 56, 1150-1157, 2008.

Nittrouer, C. A. and DeMaster, D. J.: The Amazon shelf setting: tropical, energetic, and influenced by a larger river, Cont. Shelf Res., 16, 553-573, 1996.

Novara, A., Gristina, L., La Mantia, T., and Rühl, J.: Soil carbon dynamics during secondary succession in a semi-arid Mediterranean environment, Biogeosciences Discuss., 8, 11107-11138, doi:10.5194/bgd-8-11107-2011, 2011.

Ogrinc, N., Markovics, R., Kanduc, T., Walter, L. M., and Hamilton, S. K.: Sources and transport of carbon and nitrogen in the River Sava watershed, a major tributary of the River Danube, Appl. Geochem., 23, 3685-3698, 2008.

Palanques, A., Durrieu de Madron, X., Puig, P., Fabres, J., Guillén J.,Calafat, A., Canals, M., Heussner, S., and Bonnin, J.: Suspended sediment fluxes and transport processes in the Gulf of Lions submarine canyons: The role of storms and dense water cascading, Mar. Geol., 234, 43-61, 2006.

Paloc, H.: Carte Hydrogéologique de la France: Région karstique nord-montpelliéraine, Notice explicative, Mémoires du B.R.G.M., 50, B.R.G.M., Paris, 1967.

Pauc, H.: Formation of the Aude, Orb and Herault prodeltas and their characterisation using physicochemical and sedimentological parameters. Mar. Geol., 222/223, 335-343, 2005.

Pettine, M., Patrolecco, L., Camuso, M., and Crescenzio, S.: Transport of carbon and nitrogen to the northern Adriatic Sea by the Po River, Est. Coast. Shelf Sci., 46, 127-142, 1998.

Pont D., Simonnet J.-P., and Walter A. V.: Medium-term Changes in Suspended Sediment Delivery to the Ocean: Consequences of Catchment Heterogeneity and River Management (Rhône River, France), Est. Coast Shelf Sci., 54, 1-18, 2002 
Poulos, S. E. and Drakopoulos, P. G.: A reassessment of the Mediterranean river runoff, Rapp. Comm. Int. Mer Medit., 36, p. 76, 2001.

Riera., P. and Richard, P.: Temporal variation of $\delta^{13} \mathrm{C}$ in particulate organic matter and oyster Crassostera gigas in Marennes-Oléron Bay (France): effect of freshwater inflow, Mar. Ecol. Prog. Ser., 147, 105-115, 1997.

Rolff, C. and Elmgren, R.: Use of riverine organic matter in plankton food webs of the Baltic Sea, Mar. Ecol. Prog. Ser., 197, 81101, 2000.

Sabater, F. and Armengol, J.:Chemical characterization of the Ter River, Limnetica, 2, 75-84, 1986.

Sage, R. F., Wedin, D. A., and Li, M.: The biogeography of C4 photosynthesis, patterns and controlling factors, in: C4 Plant Biology, edited by: Sage, R. F. and Monson, R. K., Academic Press, Toronto, 313-373, 1999.

Sanchez-Vidal, A., Pasqual, C., Kerhervé, P., Heussner, S., Calafat, A., Palanques, A., Durrieu de Madron, X., Canals, M., and Puig, P.: Across margin export of organic matter by cascading events traced by stable isotopes, northwestern Mediterranean Sea, Limnol. Oceanogr.,54, 1488-1500, 2009.

Sanchez-Vidal, A., Canals, M., Calafat, A., Lastras, G., PedrosaPàmies, R., Menéndez, M., Medina, R., Company, J. B., Hereu, B., Romero, J., and Alcoverro, T.: Impacts on the deep-sea ecosystem by a severe coastal storm, PLoS ONE, 7, e30395, doi:10.1371/journal.pone.0030395.g003, 2012.

Sanchez-Vidal, A., Higueras, M., Martí, E., Liquete, C., Calafat, A., Kerhervé, P., and Canals, M.: Riverine transport of terrestrial organic matter to the North Catalan margin, NW Mediterranean Sea, Prog. Oceanogr., 118, 71-80, 2013.

Schroeder, K., Garcia-Lafuente, J., Josey, S. A., Artale, V., Buongiorno Nardelli, B., Carrillo, A, Gačić, M., Gasparini, G. P., Herrmann, M., Lionello, P., Ludwig, W., Millot, C., Özsoy, E., Pisacane, G., Sánchez-Garrido, J. C., Sannino, G., Santole, M. N., R., Somot, S., Struglia, M., Stanev, E., Taupier-Letage, I., Tsimplis. M. N., Vargas-Yáñez, M, Zervakis, V., and Zodiati, G.: Circulation of the Mediterranean Sea and its Variability, in: The Climate of the Mediterranean Region - From the past to the future, edited by: Lionello, P., Elsevier, London, 187-256, 2012.
Sempéré, R., Charrière, B., Van Wambeke, F., and Cauwet, G.: Carbon inputs of the Rhône river to the Mediterranean Sea: biogeochemical implications, Global Biogeochem. Cy., 14, 669-681, 2000.

Serrat, P., Ludwig, W., Navarro, B., and Blazi, J. -L.: Variabilité spatio-temporelle des ?ux de matières en suspension d'un fleuve côtier méditerranéen: la Têt (France), C. R. Acad. Sci., 333, 389397, 2001.

Schäfer, J., Blanc, G., Lapaquellerie, Y., Maillet, N., Maneux, E., and Etcheber, H.: Ten-year-observation of the Gironde fluvial system: fluxes of suspended matter, particulate organic carbon and cadmium, Marine Chemistry, 79, 229e242, doi:10.1016/S0304-4203(02)00066-X, 2002.

Syvitski, J. P. M.: Sediment fluxes and rates of sedimentation, in: Encyclopedia of Sediments and Sedimentary rocks, edited by: Middleton, G. V., Kluwer Academic Publishers, Dordrecht, 600606, 2003.

Syvitski, J. P. M., Vörösmarty, C. V., Kettner, A. J., and Green, P.: Impact of humans on the flux of terrestrial sediment to the global coastal ocean, Science, 308, 376-380, 2005.

Tena, A., Batalla, R. J., Vericat, D., and Lopez-Tarazon, J. A.: Suspended sediment dynamics in a large regulated river over a 10year period (the lower Ebro, NE Iberian Peninsula), Geomorphology, 125, 73-84, 2011.

Wheatcroft, R. A. and Borgeld, J. C.: Oceanic flood layers on the northern California margin: Large-scale distribution and smallscale physical properties, Cont. Shelf Res., 20, 2163-2190, 2000.

Wissel, B. and Fry, B.: Tracing Mississipi River influences in estuarine food webs of coastal Louisiana, Oecologia, 144, 659-672, 2005. 